Ks. Mariusz Trąba

\title{
STARANIA O UWOLNIENIE KOPII OBRAZU MATKI BOŻEJ CZĘSTOCHOWSKIEJ Z JASNEJ GÓRY W OKRESIE NAWIEDZENIA ARCHIDIECEZJI KRAKOWSKIEJ (1967-1968)
}

\section{"ARESZTOWANIE" KOPII OBRAZU MATKI BOŻEJ CZESTOCHOWSKIEJ W 1966 ROKU}

Peregrynacja kopii obrazu Matki Bożej Częstochowskiej była jednym z najważniejszych elementów wielkiego programu duszpasterskiego, który w związku z obchodami Tysiąclecia Chrztu Polski, ułożył i realizował prymas Polski kard. Stefan Wyszyński. W ramach owego programu peregrynacja miała być konkretną realizacją zobowiązań, jakie naród polski podjął, składając Jasnogórskie Śluby Narodu (26 sierpnia 1956). Peregrynacja miała także stanowić duchowe przygotowanie do obchodów Milenium chrystianizacji Polski. Była ona także odpowiedzią na laicyzacyjną politykę państwa komunistycznego, które chciało usunąć z życia społecznego wszelkie przejawy religii i religijności. Kiedy okazało się, że Nawiedzenie kopii obrazu jasnogórskiego gromadzi wielkie tłumy wiernych, co nie przystawało do partyjnej wizji postępującej laicyzacji, władze zdecydowały się na rozwiązanie całej sytuacji za pomocą siły. Jako uzasadnienie stosowania represji wobec osób uczestniczących w peregrynacji oraz wobec samej kopii ikony jasnogórskiej władze podawały twierdzenia, że całe Nawiedzenie jest akcją polityczną, a nie religijną ${ }^{1}$.

' J. T o m z i ń s k i, Obraz Nawiedzenia i geneza wędrówek Bożej Matki po parafiach, [w:] Tyś wielka chlubq naszego narodu, red. K. Kunz. Częstochowa 1991, s. 436-440; J. J e 10 w i e c k a, Nawiedzenie polskich parafii przez kopię obrazu Matki Bożej Jasnogórskiej, „Studia Claromontana” t. 2(1982), s. 91-94, 99-100; A. W ó j c i k, Częstochowska Matka Boża. VI: Peregrynacja, [w:] Encyklopedia katolicka, t. 3. Lublin 1979, k. 878-879; W. Prusowski, Najbardziej znaczace akcje maryjne Prymasa Tysiaclecia, „Ateneum Kapłańskie” 2007, t. 149, z. 1(590), s. 145-151. 
W opinii władz partyjnych i państwowych całość uroczystości peregrynacyjnych była wrogim aktem, skierowanym przeciwko władzy ludowej. Głównym celem wędrówki obrazu Nawiedzenia po parafiach polskich miało być rozbicie narodu polskiego, doprowadzenie do "samorzutnego upadku komunizmu w Polsce" oraz „uchrześcijanienie” społeczeństwa. Dla obozu władzy obecność kopii obrazu Matki Bożej Częstochowskiej w czasie uroczystości milenijnych w 1966 r. jawiła się jako zorganizowane i kierowane przez Kościół referendum i próba sił pomiędzy komunizmem a katolicyzmem². W opinii Urzędu ds. Wyznań, który monitorował przebieg całej uroczystości, Nawiedzenie było okazją do popełniania wielu przestępstw i wykroczeń. Za takie uznano:

- głoszenie kazań godzących w ustrój i władze PRL;

- stosowanie wobec osób niewierzących i nie praktykujących różnych formy „nacisku i przymusu w celu zmuszenia ich do zawarcia ślubu kościelnego, ochrzczenia dzieci i uczestnictwa w nabożeństwach";

- organizowanie zgromadzeń publicznych bez uzyskania odpowiednich i wymaganych pozwoleń;

- organizowanie zgromađzeń na drogach publicznych, które powodowały ograniczenie lub utrudnienie ruchu;

- budowa łuków i bram powitalnych bez wymaganych zezwoleń nadzoru budowlanego.

W związku z taką oceną sytuacji Urząd d/s Wyznań w swej opinii, przygotowanej w 1966 r. na użytek władz państwowo-partyjnych, stwierdził: „Wobec tego kontynuowanie peregrynacji, jako imprezy służącej nadużywaniu uczuć i swobód religijnych do celów politycznych oraz stanowiącej powód do notorycznego naruszania porządku prawnego państwa, nie może być tolerowane"3.

W 1966 r. zgodnie z planami Episkopatu Polski w każdej z polskich stolic biskupich miały odbyć się uroczystości dziękczynne za 1000 lat chrześcijaństwa. Planowano także, że w czasie każdej z owych uroczystości, obecna będzie w danym mieście kopia ikony z Jasnej Góry. Wydarzenia do jakich doszło wokół wędrówki obrazu Nawiedzenia w pierwszej połowie 1966 r. były zapowiedzią tego, co stało się we wrześniu tego samego roku, kiedy to obraz ten został właściwie „internowany" przez władze na Jasnej Górze 4 .

W Krakowie władze zdecydowały się na pierwszą bezpośrednią interwencję w stosunku do kopii obrazu Nawiedzenia. Trase przejazdu obrazu Nawiedzenia przez miejscowości województwa krakowskiego oraz samo miasto Kraków ustalono w czasie spotkania arcybiskupa $\mathrm{K}$. Wojtyły z przewodniczącymi prezydiów Wo-

\footnotetext{
${ }^{2}$ Archiwum Akt Nowych [dalej: AAN], Urząd ds. Wyznań [dalej Ud/sW], syg. 138/23, k. 60. Opracowanie Urzędu d/s Wyznań pt. Peregrynacja Obrazu NMP Czestochowskiej (Warszawa, czerwiec 1966).

${ }^{3}$ Tamże, syg. 138/23, k. 62-63. Informacja w sprawie uzupetnienia czerwcowej notatki o peregrynacji.

${ }^{4}$ J. Ż a r y n, Dzieje Kościota katolickiego w Polsce (1944-1989), Warszawa 2003, s. 246.
} 
jewódzkiej Rady Narodowej i Miejskiej Rady Narodowej miasta Krakowa oraz kierownikiem Wydziału ds. Wyznań w dniu 30 kwietnia 1966 r. Komunikat o trasie przejazdu obrazu odczytano we wszystkich kościolach archidiecezji 1 maja $1966 \mathrm{r}$. Zgodnie z ustaleniami samochód z obrazem miał przejechać ul. Kazimierza Wielkiego, ul. Łobzowska, ul. Podwale, ul. Straszewskiego i od ul. Bernardyńskiej wjechać na wzgórze wawelskie. Mieszkańcy Krakowa tłumnie oczekiwali na tej trasie na przyjazdy samochodu-kaplicy. Na trasie ustawiono ok. 100 ołtarzy zbudowanych przez samych wiernych. Niestety 6 maja samochód wiozący obraz został zatrzymany pod Olkuszem, w okolicy Ogrodzieńca i skierowany do Krakowa zupełnie inna drogą. Decyzja o podjęciu takich kroków zapadła jeszcze przed rozpoczęciem uroczystości milenijnych w Krakowie. Podjęto ją na spotkaniu Kolektywu Wojewódzkiego ds. Kleru. Zatrzymanie obrazu Nawiedzenia i odeskortowanie go na Wawel inną trasa, niż to ogłaszano kilka dni wcześniej, spowodowało dezorientacje wiernych, którzy kilka godzin w ulewnym deszczu oczekiwali na przybycie obrazu. Ten zaś znalazł się w katedrze wawelskiej o godz. 19.40, podczas gdy wierni oczekiwali go prawie do północy ${ }^{5}$.

W maju 1966 r. uroczystości milenijne odbyły się w diecezji katowickiej. Według planu kopia obrazu Matki Bożej Częstochowskiej miała zostać w dniı̣ 18 maja przewieziona do Katowic, a następnie do Piekar Śląskich. Samochód z obrazem został jednak po raz kolejny zatrzymany, tym razem pod Bytomiem i skierowany bezpośrednio do Piekar.

Liczny udział, bo ok. 100 tys. wiernych, w uroczystościach milenijnych w Lublinie (5-6 VI 1966) wzbudził irytację i gniew władz partyjnych i administracyjnych. Już 6 czerwca przewodniczący PWRN w Lublinie, Paweł Dąbek, w rozmowie z biskupem Janem Mazurem, oświadczył, że władze podjęły decyzję o zmianie trasy przekazu samochodu z obrazem Nawiedzenia na trasie Lublin Warszawa. Uderzało to przede wszystkim w ludzi, którzy chcieli choć na chwilę ujrzeć kopie obrazu jasnogórskiego i oczekiwali na to wydarzenie na trasie przejazdu kaplicy-samochodu. Wyjazd obrazu Nawiedzenia z Lublina, rankiem 7 czerwca, odbył się spokojnie, choć z licznym udziałem wiernych, a samochód wiozący obraz był do rogatek miasta pchany przez studentów. Jednakże już poza granicami Lublina, w Wojciechowicach, lokalne władze partyjne, prawdopodobnie kierujące się dyrektywami odgórnymi, nakazały obraz zatrzymać, okryć go brezentową płachtą i szybko przewieźć do Częstochowy. Biskup J. Mazur sam poprowadził samochód-kaplicę ${ }^{6}$.

${ }^{5}$ T. Fil i p czak, Reakcja krakowskich wtadz na obchody Millennium w świetle zachowanej dokumentacji Komiteru Wojewódzkiego PZPR, Wojewódzkiej Rady Narodowej i Miejskiej Rady Narodowej w Krakowie, [w:] Millennium polskie. Walka o rzad dusz, Warszawa 2002, s. 81-82; A. D u d e k, Panstwo i Kościót w Polsce 1945-1970, Kraków 1995, s. 199-200.

${ }^{6}$ E. W i e rzb i ck a, Obchody Tysiqclecia Chrztu Polski $w$ diecezji lubelskiej $w$ świetle akt KW PZPR w Lublinie, [w:] Millennium polskie..., s. 96; A. D u d e k, Państwo i Kościół..., s. 202. 
$\mathrm{Na}$ obchody milenijne w Olsztynie obraz Nawiedzenia w ogóle nie dotarł. Milicja zatrzymała samochód-kaplicę i skierowała go bezpośrednio do Fromborka. W dniu 10 czerwca 1966 r. obraz został zabrany z Jasnej Góry przez przedstawicieli biskupa Józefa Drzazgi, wikariusza kapitulnego diecezji warmińskiej. Po drodze do Fromborka obraz miał zatrzymać się w siedmiu miejscowościach, gdzie miał być wystawiony i gdzie miały odbyć się uroczystości religijne. Owo Nawiedzenia udało się przeprowadzi jedynie w Nidzicy (11 czerwca). Prawdopodobnie, aby uniemożliwić przeprowadzenie podobnych uroczystości w kolejnych miastach, władze podjęły decyzję o ,aresztowaniu” obrazu. Wieczorem 12 czerwca o godz. 19.15 pod pretekstem kontroli MO samochód z obrazem Nawiedzenia został zatrzymany na drodze z Nidzicy do Olsztynka. Ks. Tadeusz Borkowski, któremu zlecono opiekę nad obrazem Nawiedzenia w czasie jego przejazdu do Olsztyna, odmówił wydania kluczyków od wołgi, którą transportowano obraz. Został on za to zatrzymany i siła przez trzech milicjantów wniesiony do milicyjnej furgonetki. W czasie rewizji na Komendzie Powiatowej MO w Nidzicy odebrano mu kluczyki. Tymczasem samochód z obrazem został wzięty na hol, a następnie uruchomiono go wyciaggając stacyjkę i łącząc kable. Samochód z obrazem Nawiedzenia prawie przez całą drogę od miejsca zatrzymania do Fromborka prowadził nieznany z nazwiska pułkownik ${ }^{7}$. Stanowczy protest przeciwko takiemu potraktowaniu obrazu Nawiedzenia oraz osób go przewożących złożył w piśmie do władz administracyjnych biskup J. Drzazga, twierdząc, że wydarzenia, które zaszły stanowią naruszenie postanowień Konstytucji PRL, gwarantującej w art. 70 Kościołowi swobodne wypełnianie swoich funkcji religijnych ${ }^{8}$.

Kiedy zaś 20 czerwca 1966 r. przewożono obraz Nawiedzenia z Fromborka do Warszawy został on dwukrotnie zatrzymany przez służby bezpieczeństwa. W wypadku pierwszego zatrzymania przeprowadzono jedynie dokładną rewizję samochodów. Drugie zatrzymanie miało miejsce w miejscowości Liksajny, na drodze pomiędzy Pasłękiem a Ostródą. Kard. S. Wyszyński, który towarzyszył obrazowi Nawiedzenia w tej podróży, prawdopodobnie liczył, że jego obecność powstrzyma władze od interwencji. Te były jednak zdecydowane posunąc się daleko. Obraz odebrano kard. S. Wyszyńskiemu i przewieziony go pod eskortą sił bezpieczeństwa inną trasą do katedry św. Jana w Warszawie?.

Uroczyste powitanie obrazu Nawiedzenia na terenie archidiecezji warszawskiej miało nastąpić po południu 21 czerwca w Nowym Dworze. Tego samego dnia wieczorem obraz miał zostać przewieziony do kościoła św. Stanisława Kostki na Żoliborzu i tam miało nastapić jego uroczyste powitanie przez duchowieństwo

T. B orkowski, Sprawozdanie z przewiezienia kopii obrazu Matki Bożej Częstochowskiej z Jasnej Góry do Fromborka (Olsztyn, 13 czerwca 1966), [w:] P. R a i n a, „Te Deum” Narodu Polskiego. Obchody Tysiqclecia Chrztu Polski w świetle dokumentów kościelnych, Olsztyn 1991, s. 227-229.

${ }^{8}$ Pismo Ordynariusza Warmińskiego do Przewodniczqcego Prezydium Wojewódzkiej Rady Narodowej Mariana Gotowca (Olsztyn, 13 czerwca 1966), [w:] tamże, s. 229.

${ }^{9}$ A. D u d e k, Państwo i Kościót..., s. 202-203. 
i wiernych stolicy. Dopiero 22 czerwca planowano w procesji wprowadzić ikonę Matki Bożej Częstochowskiej do archikatedry św. Jana. Jednakże, zupełnie niespodziewanie 20 czerwca, ok. godz. 21.00 samochód marki żuk prowadzony przez funkcjonariusza MO i przewożący obraz Matki Bożej podjechał pod budynek kanonii katedry św. Jana. Wraz z obrazem do Warszawy przybyli ks. bp Franciszek Musiel, biskup pomocniczy diecezji częstochowskiej, o. Jerzy Tomziński, generał zakonu paulinów oraz ks. Leopold Włudyka, notariusz kurii warszawskiej. Obraz wyjęto z samochodu i w spontanicznie zorganizowanej procesji, przy śpiewie wiernych, przeniesiono do zakrystii katedralnej. Tam ustawiono go w oknie, za kratami, twarza do ulicy. Zdjęcie ukazujące obraz za kratami i modlących się przed nim na ulicy wiernych jest jednym $\mathrm{z}$ najwymowniejszych symboli czasu peregrynacji i walki jaką państwo prowadziło wówczas z Kościołem. Po zakończeniu uroczystości milenijnych w Warszawie, które trwały do 26 czerwca 1966 r., obraz Nawiedzenia do pierwszych dni września tego roku pozostał $w$ archikatedrze św. Jana ${ }^{10}$.

W sierpniu 1966 r. kard. S. Wyszyński zadecydował, że uroczystości milenijne w Sandomierzu odbędą się bez obecności obrazu Matki Bożej Częstochowskiej. Miał być to protest przeciwko zniewagom, jakich dopuszczono się wobec świętego wizerunku w czasie przewożenia obraz w okresie wcześniejszym ${ }^{11}$. Kuria Diecezjalna w Sandomierzu wydała specjalny komunikat, który odczytano w kościołach diecezji. W jego treści podkreślono, iż wobec trudności i przykrych wypadków jakie nastąpiły podczas przewożenia obrazu Matki Bożej Częstochowskiej z Lublina do Częstochowy oraz z Olsztyna do Warszawy, a także wobec braku zapewnienia ze strony władz państwowych, że ta sytuacja się nie powtórzy, cudowny obraz pozostanie w katedrze św. Jana w Warszawie ${ }^{12}$.

We wrześniu 1966 r. peregrynacja obrazu Matki Bożej Częstochowskiej miała rozpocząć się w diecezji katowickiej. Biskupi katowiccy informowali prymasa S. Wyszyńskiego, że władze partyjne i administracyjne Śląska są niezwykle wrogo nastawione wobec tych uroczystości. Prezydium Wojewódzkiej Rady Narodowej w Katowicach powołując się na względy bezpieczeństwa i utrzymania porządku na drogach publicznych i $\mathrm{w}$ gęsto zaludnionym obszarze, zgodnie $\mathrm{z}$ art. 10 ustawy z dnia 29 marca 1962 r. o zgromadzeniach, „odmówiło zezwolenia na przeprowadzenie $w$ dotychczas praktykowanej formie obchodów w ramach peregrynacji na terenie województwa katowickiego". O takie decyzji poinformowano stronę kościelna w czasie spotkań z przedstawicielami Kurii Diecezjalnej w Katowicach w dniach 18 i 20 sierpnia 1966 r. ${ }^{13}$ Jednakże biskupi polscy zebrani na Konferencji

\footnotetext{
${ }^{10}$ Przebieg umoczustości - wspomnienia uczestnika, [w:] P. R a i n a, „Te Deum" Narodu Polskiego..., s. 252.

" B.S t a n a z z e k, Diecezja sandomierska w powojennej rzeczywistości politycznej w latach 1945-1967, t. 2; Duszpasterstwo i laicyzacja życia spotecznego, Sandomierz 2006, s. 106-107.

${ }^{12}$ Kommikat Kurii Diecezjalnej Sandomierskiej w sprawie ochrony obrazu Matki Boskiej Częstochowskiej przed ewentialnq profanacjq (Sandomierz, sierpień 1966), [w:] P. R a i n a, Kościót w PRL. Kościót katolicki a państwo w świetle dokumentów 1945-1989, t. 2: Lata 1960-1974, Poznań 1995, s. 404.

${ }^{13}$ Instytut Pamięci Narodowej - Komisja Ścigania Zbrodni przeciwko Narodowi Polskiemu Oddziałowe Biuro Udostępniania i Archiwizacji Dokumentów w Katowicach [dalej IPN Ka], syg. IPN Ka
} 
Episkopatu Polski w dniach 31 sierpnia i 1 września podjęli decyzję, że Nawiedzenie $w$ parafiach diecezji katowickiej odbędzie się tak jak planowano, nawet jeżeli władze nie dopuszczą na Śląsk obrazu Nawiedzenia ${ }^{14}$. Planowano, że zostanie on przewieziony z Warszawy do Katowic w dniu 2 wrześnian 1966 r. W skład delegacji, która udała się do stolicy, aby sprowadzić go na Śląsk, wchodzili biskup pomocniczy diecezji katowickiej Józef Kurpas, ks. prałat Walter Wrzoł oraz ks. Arnold Szuła.

W czasie przewożenia obrazu Nawiedzenia został on jednak zatrzymany i pod eskortą sił policyjnych odwieziony na Jasną Górę ${ }^{15}$. Bp sufragan katowicki J.Kurpas, który został 2 września zatrzymany przez władze i przewieziony do Częstochowy, opisał owo wydarzenia w sposób następujący:

„W piątek, dnia 2 września 1966 r. zostałem w drodze z Warszawy do Katowic zatrzymany na terenie Dąbrowy Górniczej przez patrol MO i po godzinnym z góra przetrzymaniu na ruchliwej trasie siła odprowadzony w konwoju kilku samochodów milicyjnych do Częstochowy.

W czasie postoju poprosiłem po raz o wyjaśnienia, o powody zatrzymania. Posterunkowi stwierdzali kilkakrotnie, że przejazd nie jest legalny, w papierach nie ma błędu, stan techniczny wozu w porządku, żaden przepis ruchu drogowego nie został naruszony. Na wszystkie indygacje jedna wciąż pada odpowiedź: mamy rozkaz, dalej nie pojedziecie, nie róbcie tego na naszym terenie, zawracajcie.

Gdy w końcu nadjechał major w towarzystwie cywila i po dwukrotnej naradzie kazał umundurowanym zasiąść za kierownica, raz jeszcze zaprotestowałem: 1) przeciw znieważeniu Obrazu (który przewożony prywatnie i bez kaplicy, ale legalnie!), 2) przeciw nieprawnemu zatrzymaniu na drodze, 3) przeciw gwaltownemu uprowadzeniu kilu obywateli. Wobec groźby użycia przemocy ustapiłem. Gdyśmy ruszyli w konwoju pięciu wozów milicyjnych, minęly nas 4 szturmówki pełne MO na sygnałach świetlnych. Sygnały zostały od razu wygaszone. Przejeżdżając przez Będzin jeden z księży wykorzystał moment zatrzymania konwoju na skutek korka drogowego i wysiadł z Nysy. Od razu wyskoczył major $\mathrm{j}$ krzykiem na cała ulice, pod groźbą kary kazał mu wsiąść do wozu z powrotem.

Na Jasnej Górze przed klasztorem wozy MO zatrzymały się i kazano nam wjeżdżać na dziedzinie. Wtedy ks. referent Szuła i ks. prałat Wrzoł wysiedli z Nysy, odmówili wjazdu, twierdząc, że - jesteśmy na miejscu, drogę dalszą znamy i nie ma potrzeby, aby nas dalej pchano!

085/1 t. 4 cz. 2, k. 133-134. Postanowienie Prokuratury Wojewódzkiej o odmowie ścigania Iprzestępstwa znieważania obrazu Matki Bożej Częstochowskiej] (projekt - wrzesień 1966).

${ }^{14}$ A. D z i u r o k, Ł. M a r e k, Matka Boska Niechciana. O zatrzymaniu kopii obrazu Matki Boskiej Czestochowskiej w 1966 r, ,,Śląsk" 2006, nr 11(133), s. 14.

${ }^{15}$ Szerzej na ten temat: A. D z i u ro k, E. M a re k, Matka Boska Niechciana...; J. M y s z o r, Historia diecezji katowickiej, Katowice 1999, s. 532-533. 
Po krótkiej, ale ostrej wymianie zdań, przy czym dwukrotnie grożono ks. Szle użyciem gumy i wyrażano się do niego per «ty» (na co «cywil» odezwał się «Majorze, spokojnie!») gwałtem oderwano stacyjkę, do Nysy wsiadł kapitan, krótkim spięciem uruchomił silnik i wjechał na dziedziniec klasztorny"16.

W klasztorze jasnogórskim obraz Nawiedzenia pozostał do czerwca 1972 r. $^{17}$.

Interesujące są argumenty za pomocą których władze województwa śląskiego uzasadniały konieczność zatrzymania obrazu Matki Bożej i niedopuszczenia go na Śląsk. Oczywiście zawsze pierwszym argumentem w tym dowodzeniu było stwierdzenie, że peregrynacja jest akcją polityczną Episkopatu, nastawioną na konfrontację z ludowym państwem. I żadne tłumaczenia strony kościelnej nie mogły zmienić tego stanowiska władz partyjno-państwowych. Jednocześnie jednak władze na Śląsku stwierdzały, że „peregrynacja $w$ dotychczasowej postaci, przede wszystkim przez to, że najistotniejszym jej elementem było wyjście mas wierzących i kleru poza obręb kościoła, groziło naszemu wysoko rozwiniętemu i silnie zurbanizowanemu województwu wieloma ujemnymi konsekwencjami natury nie tylko społeczno-politycznej, ale i gospodarczej". W opinii władz Nawiedzenie doprowadziłoby do blokady dróg i ulic, a w konsekwencji do przestojów zakładów pracy i strat gospodarczych. Trzeci argument władz, którym uzasadniano zatrzymanie obrazu Matki Bożej we wrześniu 1966 r. oparto na przesłance, iż teren Śląska zamieszkały jest w dużej liczbie przez osoby niewierzące lub innych wyznań, których przekonania należy chronić - „(...) tereny objęte działaniem diecezji katowickiej charakteryzują się większym, níz gdzie indziej ilościami ludzi niewierzących oraz wyznawców innych wyznań, których uczucia obrażałaby publiczna manifestacja wojującego katolicyzmu"18.

Stanowisko Episkopatu Polski wobec tych wydarzeń było jednoznaczne działania władz maja charakter profanacji. Opinia ta została jasno sformułowana i wyrażona w proteście, który w dniu 22 listopada 1966 r. prymas S.Wyszyński wraz z innymi biskupami skierowali do Rady Państwa. Biskupi nazwali zatrzymanie, przetrzymywanie obrazu i zmianę trasy jego wędrówki jako „czynne znieważenie". Znieważenie owo, stwierdzili biskupi, „polega nie na jakimś materialnym uszkodzeniu samego przedmiotu, jakim jest ów obraz. Zniewaga ta dotyczy natomiast całego stosunku, w jakim obraz ów pozostaje do ludzi wierzących i w jakim ludzie ci swój stosunek do niego ukształtowali na przestrzenie całych stuleci i dziś nadal kształtuję. Ludzie wierzący bowiem czczą w obrazie samą Osobę Bogurodzicy, a z owej czci czerpią pobudkę do pracy nad sobą i do spełniania swych obowiązków, również społecznych i zawodowych. (...) Odebranie tego Obrazu doko-

${ }^{16}$ IPN Ka, syg. IPN Ka 085/1 t. 4 cz. 2, k. 287-288. Pismo bpa J.Kuipasa do Prokuratora Wojewódzkiego w Katowicach z 10 IX 1966 I:

${ }^{17}$ Cz.R y s z k a, Infulat z Suchedniowa. Kraków-Suchedniów 2007, s. 189-256.

${ }^{18}$ IPN Ka, syg. IPN Ka 085/1 t. 4 cz. 2, k. 33. [Wydzial Administracyjny KW PZPR w Katowicach], Ocena przebiegu peregrynacji $w$ diecezji katowickiej (Katowice, 16 XI 1967). 
nane siła, a wraz z tym udaremnienie jego funkcji religijnej jest wtargnięciem w dziedzinę czysto religijną przy użyciu przemocy fizycznej, a równocześnie stanowi wyraźne pogwałcenie uczuć religijnych oraz ich bolesną obrazę"19. W sposób szczególny - zdaniem biskupów - pogwałcenie praw ludzi wierzących w Polsce daje się odczuć, kiedy to, w czasie wyznaczonym na Nawiedzenie wierni danej parafii gromadzą się w swym kościele, a obraz Matki Bożej nie przybywa i wszystkie uroczystości dokonują się wobec pustej ramy ${ }^{20}$.

Swój protest powtórzyli biskupi w czerwcu 1968 r. Trwała już wówczas peregrynacja w archidiecezji krakowskiej, która prowadzono tak samo jak na terenie diecezji katowickiej bez obrazu, wystawiając puste ramy. Ogłoszono wówczas list pasterski Episkopatu Polski w sprawie uwięzionego na Jasnej Górze obrazu Nawiedzenia. Biskupi informowali wiernych, że uwięzienie obrazu nastąpiło na skutek działań władz i że to one pilnują, aby obraz nie opuścił klasztoru jasnogórskiego. Jednocześnie dzień 26 sierpnia 1968 r. ogłoszono dniem ,wynagrodzenia Pani jasnogórskiej, Królowej Polski, wszystkich zniewag oraz dniem modlitwy o wolność w Nawiedzeniu Obrazu". W całym kraju zarządzono odprawienie wieczornego nabożeństwa ku czci Matki Bożej jasnogórskiej21.

Tymczasem postanowiono jednak, że peregrynacja na terenie diecezji katowickiej, pomimo nieobecności obrazu, będzie kontynuowana. W miejsce kopii ikony jasnogórskiej w kościołach, w których odbywało się Nawiedzenie wystawiono pustą ramę po obrazie. Często była ona przystrojona kwiatami lub czarnym kirem. W części kościołów na czas Nawiedzenia w centralnym miejscu świątyni umieszczano inną kopię obrazu Matki Bożej Częstochowskiej. Władze za swój sukces w diecezji katowickiej uznały fakt, że puste ramy nie były przewożone z kościoła do kościoła, ale w każdej z parafii wykonywano je samodzielnie. Właśnie w diecezji katowickiej, wobec nieobecności wędrującego obrazu, zaczęto termin peregrynacja zastępować pojęciem Nawiedzenia, które lepiej oddawało duchową stronę przeżywanych uroczystości ${ }^{22}$. W ten właśnie sposób władze komunistyczne swoja decyzją o niedopuszczeniu kopii obrazu Królowej Polski na Śląsk niewątpliwie przyczyniły się do pogłębienia duchowego zrozumienia owej uroczystości.

W dniu 29 października 1967 r. w Panewnikach odbyła się uroczystość przekazania Nawiedzenia z diecezji katowickiej do archidiecezji krakowskiej. Zarówno na ołtarzu polowym, jak i nad ołtarzem znajdującym się wewnątrz kościoła oo. franciszkanów, zawieszono puste ramy przyozdobione kwiatami. W swoim wystą-

19 Protest Episkopatu Polski skierowany do Rady Państwa w sprawie znieważania obrazu Matki Boskiej Częstochowskiej przez władze administracyjne oraz gwatcenie uczuć religijnych (Warszawa, 22 listopada 1966), [w:] P. R a i n a, Kościól w PRL.., t. 2, s. 406.

${ }^{20}$ Tamże, s. 406-407.

${ }^{21}$ Stowo Episkopatu Polski w sprawie uwiezionego na Jasnej Górze obrazu Nawiedzenia Matki Bożej Częstochowskiej (Gniezno, 28 czerwca 1968), [w:] P. R a i n a, Kościót w PRL..., t. 2, s. 509-511.

${ }^{22}$ IPN Ka, syg. IPN Ka 085/1 t. 4 cz. 2, k. 36-37. [Wydział Administracyjny KW PZPR w Katowicach], Ocena przebiegu peregrynacji w diecezji katowickiej (Katowice, 1 XI 1967). 
pieniu biskup H. Bednorz stwierdził, że co prawda peregrynacja odbyła się bez kopii obrazu Najświętszej Maryi Panny Częstochowskiej, ale w jej trakcie wierni czuli duchową obecność Matki Bożej w parafiach, w których dokonywało się Nawiedzenie. Przyznał także, że zarówno on, jak i jego współpracownicy, obawiali się niepowodzenia całego przedsięwzięcia peregrynacji, ale „rzeczywistość obaliła te obawy i uroczystości Nawiedzenia były udane". Do nieobecności kopii obrazu jasnogórskiego nawiązał w swoim wystąpieniu także prymas S. Wyszyński, który powiedział: „Oczywiście mieliśmy potrzebę oglądania Jej w jasnogórskim obrazie. I potrzebę, i prawo, jak to przysługuje wolnym dzieciom Bożym w wolnej ojczyźnie" $^{\text {"23. }}$.

Obecni na uroczystości w Panewnikach pracownicy SB zauważyli i odnotowali jedną, charakterystyczną cechę wystapień biskupa $\mathrm{H}$. Bednorza oraz kard. K.Wojtyły. Biskupi owi zaprzestali używania terminu „peregrynacja”, ale zaczęli mówić o przekazaniu i przejęciu „wspaniałego nabożeństwa Nawiedzenia maryjnego archidiecezji krakowskjej”"24. Była to oczywista konsekwencja nieobecności kopii ikony jasnogórskiej w czasie peregrynacji. Biskupi zaczęli więc mocniej podkreślać duchową obecność Matki Bożej, nawiedzającej kolejne diecezji i parafie.

\section{STARANIA KARD. KAROLA WOJTYŁY O UMOŻLIWIENIE PEREGRYNACJI KOPII OBRAZU MATKI BOŻEJ CZĘSTOCHOWSKIEJ W ARCHIDIECEZJI KRAKOWSKIEJ}

Dla kard. K. Wojtyły nieobecność obrazu Matki Bożej Częstochowskiej w czasie peregrynacji odbywającej się w parafiach jego archidiecezji w 1967 i 1968 r. była bolesną obrazą uczuć religijnych wszystkich wiernych. Wielokrotnie zabiegał u władz o uwolnienie obrazu z Jasnej Góry, zapewniając przy tym, że Nawiedzenie nie jest skierowane przeciwko obozowi radzącemu, czy ustrojowi PRL, ale jest aktem czysto religijnym, który sprawowany będzie w miejscach kultu. Kiedy władze odmówiły przekazania obraz Nawiedzenia do archidiecezji krakowskiej metropolita w swoich wypowiedziach nie ustawał w przypominaniu wiernym, jak wielka obraza wobec świętości narodowej jest zatrzymanie obraz na Jasnej Górze i nie dopuszczenie go do peregrynacji oraz tłumaczeniu jaki jest sens wystawienia pustych ram w czasie uroczystości, które nie są tylko kawałkiem drewna, ale symbolem. W szeregu swoich wypowiedzi, wobec fizycznej nieobecności samego obrazu, kard. K. Wojtyła starał się także pogłębić i przybliżyć wiernych duchowe znaczenie całej uroczystości Nawiedzenia.

Jedną z pierwszych publicznych wypowiedzi kard. K. Wojtyły na temat nieobecności obraz Nawiedzenia w czasie peregrynacji na terenie archidiecezji kra-

\footnotetext{
${ }^{23}$ Tamże, syg. IPN Ka 056/15, k. 266. Informacja dot. zakończenia uroczystości peregrynacyjnych w' diecezji katowickiej (Katowice, 29 X 1967 r.).

${ }^{24}$ Tamże, k. 266.
} 
kowskiego był jego list pasterski skierowany do duchowieństwa i wiernych archidiecezji Cel i znaczenie Nawiedzenia obrazu Matki Bożej Częstochowskiej w parafiach Archidiecezji Krakowskiej. Odczytano go w kościołach archidiecezji 8 października $1967 \mathrm{r}$. W liście tym metropolita krakowski poinformował wiernych, że pomimo faktu, że władze świeckie nie dopuściły do przewiezienia obrazu na teren diecezji katowickiej, peregrynacja na jej terenie odbyła się zgodnie z ustalonym planem, a „nieobecność samego obrazu - zaznaczona przy pomocy pustych ram nie przeszkodziła duchowej i moralnej obecności Maryi, którą Samą czcimy i do której Samej się zwracamy". Jak zauważył metropolita sytuacja ta jeszcze bardziej podkreśliła i ugruntowała poczucie duchowej obecności Maryi w nawiedzanych parafiach $^{25}$.

W tym samym liście kard. K. Wojtyła zwrócił się z otwartym apelem do władz państwowych o to, aby obraz mógł przybyć do parafii archidiecezji:

„Do władz świeckich oczywiście zwracamy się - apelując do konstytucyjnej zasady wolności sumienia i wyznania, aby zatrzymany i specjalnie strzeżony na Jasnej Górze Obraz Nawiedzenia, mógł przybyć do naszej Archidiecezji. Chodzi tutaj o elementarne prawo wszystkich ludzi wierzacych: o prawo spełniania kultu religijnego $i$ to $w$ zasadzie w obrębie miejsc dla tego kultu przeznaczonych. Obraz nie byłby przenoszony z parafii do parafii procesjonalnie, ale byłby przewożony w zamkniętym samochodzie. Witany zaś i żegnany w obrębie sakralnym. Wyjątkowe sytuacje byłyby $z$ reguły uzgadniane $z$ odnośnymi czynnikami. W tych okolicznościach dalsze niedopuszczenie do parafii Obrazu Nawiedzenia, który jest szczególnym przedmiotem kultu religijnego, musiało by być oceniane przez ludzi wierzących jako wyraźne naruszenie podstawowych uprawnień oraz działania na ich duchową szkodę"26.

Już w sierpniu 1967 r. władze otrzymały od Służby Bezpieczeństwa informację, że metropolita krakowski zamierza w najbliższym czasie opracować i przesłać do Przewodniczącego Rady Państwa pismo, w którym będzie prosił o zezwolenie na peregrynację po archidiecezji krakowskiej jednej, dużej kopii obrazu Matki Bożej Częstochowskiej. Kopia owa miała zastapić eksponowanie w czasie Nawiedzenia pustych ram. Z informacji zdobytych przez SB wynikało, że kard. K. Wojtyła wyrażał nadzieję, że władze centralne wydadzą takową zgodę $e^{27}$.

Informacje SB były prawdziwe. W dniu 15 września 1967 r. kard. K. Wojtyła skierował pismo do Zbigniewa Skolickiego, przewodniczącego Prezydium Rady

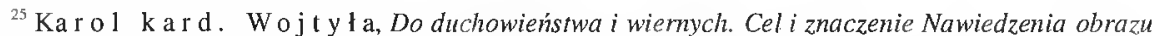
matki Bożej Czesstochowskiej w parafiach Archidiecezji Krakowskiej (List pasterski na dzień 8 października 1967 r.), [w:] Nawiedzenie obrazu Matki Bożej Jasnogórskiej w Archidiecezji Krakowskiej (Podręcznik dla kapłanów), Kraków 1967 [maszynopis powielany], s. 2-3.

${ }^{26}$ Tamże, s. 3.

${ }^{27}$ Instytut Pamjęci Narodowej - Komisja Ścigania Zbrodni przecjwko Narodowi Polskjemu Oddziałowe Biuro Udostępniania i Archiwizacji Dokumentów w Krakowie [dalej IPN Kr], syg. IPN Kr 039/27 t. 10, k. 455. Wyciąg z inf. dotyczącej przygotowań do uroczystości kościelnych (15 VIII 1967 r.). 
Narodowej m. Krakowa oraz Józefa Zagórzańskiego, przewodniczącego Prezydium Wojewódzkiej Rady Narodowej w Krakowie w sprawie zwolnienia kopii obrazu jasnogórskiego. Poinformował on wadze, iż Nawiedzenie rozpocznie się 4 listopada i trwać będzie około roku, a następnie stwierdził: „Świadomy swych uprawnień, jak również odpowiedzialności w stosunku do wiernych Archidiecezji Krakowskiej, zwracam się niniejszym do Pana Przewodniczącego, jako Przedstawiciela władzy administracyjnej, będącego Gospodarzem terenu, na którym nastąpi nawiedzenie, aby mogło ono odbyć się w duchu poszanowania dla uczuć religijnych ludzi wierzących, aby do kościołów parafii Archidiecezji Krakowskiej mógł przybyć wizerunek Matki Boskiej Jasnogórskiej zatrzymany obecnie w Częstochowie" ${ }^{28}$. W piśmie swoim kardynał $\mathrm{K}$. Wojtyła podkreślił, iż nie powołuje sį̨ na przepisy prawa, ale odwołuje się do argumentów społecznych, kulturalnych i wyznaniowych - większość społeczeństwa archidiecezji to katolicy; peregrynacja ma czysto religijny charakter; ziemia krakowska zawsze szczyciła się poszanowaniem uprawnień wyznaniowych, a wszelkie uroczystości religijne będą odbywały się na terenie kościołów i miejsc sakralnych. W końcowej czesści pisma metropolita krakowski stwierdził: „Moim najgłębszym pragnieniem jest, aby ziemia krakowska nadal szczycić się mogla poszanowaniem uprawnień wyznaniowych obywateli, aby wzajemne stosunki władz administracyjnych, wyznawców wszelkich wyznań i niewierzących, mogły układać się na zasadzie wzajemnej tolerancji i poszanowania". Dowodem poszanowania wolności wyznawania miała być w opinii kardynała właśnie zgoda władz administracyjnych na przybycie do archidiecezji krakowskiej wizerunku Matki Bożej Częstochowskie ${ }^{29}$. Odpis pisma ks. kardynała K. Wojtyły przesłano także premierowi Józefowi Cyrankiewiczowi. Jednocześnie w krótkim piśmie kardynał zwrócił się także do premiera rządu PRL „z prośbą o spowodowanie zwolnienia obrazu z Częstochowy"30.

Odpowiedź na pismo kardynała z Krakowa przygotowano w Warszawie przy współpracy Urzędu d/s Wyznań oraz KC PZPR. Istniało przynajmniej pięć wersji owej odpowiedzi. Pierwsza $z$ nich była najkrótsza i zawierała jedynie dwa stwierdzenia: po pierwsze - Prezes Rady Ministrów upoważnia przewodniczącego PRN m. Krakowa do podjęcia decyzji w odnośnej sprawie oraz po drugie - w porozumieniu z przewodniczącym PWRN w Krakowie „władze państwowe nie wyrażają zgody na odbycie peregrynacji obrazu Matki Bożej Częstochowskiej w Archidiecezji Krakowskiej”3!. W wersji czwartej pisma do kard. K. Wojtyły pojawiło się już szersze wyjaśnienie dlaczego władze nie zezwalają na odbycie Nawiedzenia oraz została podjęta polemika $\mathrm{z}$ argumentami zaprezentowanymi przez metropolitę kra-

${ }^{28}$ Archiwum Kurii Metropolitalnej w Krakowie [dalej: AKMKr], Akta Kancelarii Kurii Metropolitalnej [dalej: AKKM], Teczka: Peregrynacja obrazu Matki Boskiej Częstochowskiej (pisma Episkopatu i Kurii przesłane do Władz Państwowych i odpowiedzi na te pisma), b.p.

${ }^{20}$ Tamże, b.p.

${ }^{30} \mathrm{AAN}, \mathrm{Ud} / \mathrm{sW}$, syg. 80/6, k. 28. Pismo kard. K. Wojtyty do premiera J. Cyrankiewicza z $15 \mathrm{IX} 1967 \mathrm{r}$.

${ }^{31}$ Tamże, syg. 80/6, k. 225. 
kowskiego. Za ,inwektywę” władze uznały stwierdzenie jakoby obraz Matki Bożej Częstochowskiej został „,zatrzymany” w Częstochowie, gdyż przecież znajduje się on na Jasnej Górze w wyłącznej gestii generała zakonu paulinów. W tej wersji pisma znalazł się także fragment: „A rzekoma troska o dobro ziemi krakowskiej także pozostaje w sprzeczności z faktami: Czyżby jej przejawem miało być postępowanie Ks. Kardynała w dniach pobytu Prezydenta Republiki Francuskiej w Krakowie? A może także ma temu służyć nieobecność metropolity krakowskiego w obradach Synodu Biskupów w Rzymie! Coraz częściej ujawniający się w postawie Ks. Kardynała - brak szacunku dla własnych zapewnień oraz, dostrzegalna nawet dla wyższego duchowieństwa, zmienność poglądów nie mająca żadnego obiektywnego uzasadnienia - nie pozwalają na wzięcie pod uwagę tych zapewnień, o których jedynie dla porządku jestem informowany prze Ks. Kardynała (...)". Ciekawe jest, że w tej czwartej wersji pisma władz do kard. K. Wojtyły znalazł się passus dotyczący eksponowania pustych ram w czasie uroczystości Nawiedzenia „(...) władze państwowe uznają ten fakt jako potwierdzenie opinii, że hierarchii kościelnej chodzi nie tylko o faktyczną wędrówkę kopii obrazu MB, ile raczej o organizowanie demonstracji publicznej o charakterze politycznym" ${ }^{32}$.

Ostateczną wersję powyższego pisma, przygotowanego w Urzędzie d/s Wyznań, zaakceptował Wydział Administracyjny KC PZPR w Warszawie w dniu 23 października 1967 r. Zdecydowano, że odpowiedzi na pismo kardynała nie udzieli premier Cyrankiewicz, ale wspólnie uczynia to przewodniczący PWRN i PRN m. Krakowa. Z ostatecznej wersji pisma usunięto także fragmenty o przetrzymywaniu kopii obrazu na Jasnej Górze oraz o umieszczaniu w kościołach pustej ramy po obrazie ${ }^{33}$.

Odpowiedź ze strony władz administracyjnych nadeszła do Kurii krakowskiej po ponad miesiąca, już tuż przed rozpoczęciem uroczystości Nawiedzenia, albowiem w dniu 26 października 1967 r. W swym tonie była ona bardzo ostra i stanowią zupełne przeciwieństwo stanowiska kard. K. Wojtyły, wzywającego do poszanowania praw wszystkich obywateli. Premier J. Cyrankiewicz zlecił udzielenie odpowiedzi kardynałowi przez wojewódzkie władze administracyjne, a te w swym piśmie stwierdziły, że „zwracanie się o „zwolnienie” kopii obrazu (...) jest ignorowaniem rzeczywistości i faktów jakie zaistniały". W ich opinii organizatorzy Nawiedzenia wielokrotnie naruszali porządek publiczny i nadali całej uroczystości charakter demonstracji politycznej. W takiej to sytuacji władze administracyjne zostały zmuszone „do cofnięcia zgody na dalszą wędrówkę kopii obrazu, która znajduje się na swoim właściwym, tradycyjnym miejscu w klasztorze zakonu paulinów w Częstochowie". Opierając się na takich przesłankach, a także powołując się na

\footnotetext{
${ }^{32}$ Tamże, syg, 80/6, k. 223.

${ }^{33}$ Tamże, syg. 80/6, k. 234. Pismo A.Skrzyńskiego do tow. W. Ociepki, z-cy kierownika Wydziału Administracyjnego KC PZPR (11 X 1967); tamże, k. 253. Pismo Przewodniczqcego PWRN J. Nagórzańskiego i Przewodnicząego PRN m. Krakowa Z. Skolickiego do kard. K. Wojtyly (projekt).
} 
„troskę o zachowanie spokoju i porządku publicznego, w ramach którego zabezpieczona jest w pełni wolność religijna w Polsce" władze nie wyraziły zgody na peregrynację kopii obrazu jasnogórskiego na terenie miasta Krakowa i województwa krakowskiego. Dodano także, że „pragnienie Księdza kardynała układania stosunków z władzami administracyjnymi, na zasadzie wzajemnego poszanowania, nie znajduje dotąd potwierdzenia w praktyce działania Kurii krakowskiej"34.

28 października 1967 r. kard. K. Wojtyła skierował kolejne pismo do władz państwowych w sprawie Nawiedzenia. Ponieważ odpowiedź na jego pismo z 15 września została udzielona przez władze wojewódzkie na zlecenie premiera, skierował ja na ręce J. Cyrankiewicza. Pismo władz administracyjnych uznała kardynał za insynuacje i pomówienie o czyny niedopełnione. Jeszcze raz powtórzył, że uroczystości peregrynacji mają cel religijny i taki też będą mieć charakter, z poszanowaniem wszystkich przepisów porządkowych. Kardynał zaznaczył też zdecydowanie, iż w jego zamierzeniach peregrynacja kopii obrazu Matki Bożej Częstochowskiej miała przyczynić się do „zabliźnienia bolącej rany, jaką dla szerokiego ogółu ludzi wierzących w Polsce stanowi sprawa przymusowego zatrzymania obrazu Nawiedzenia w klasztorze na Jasnej Górze”. W opinii kardynała zatrzymanie owo ma charakter "permancntncj zniewagi świętości religijnej, a zarazem obrazy uczuć ludzi wierzących". W zakończeniu listu biskup krakowski stwierdził, że w tej sytuacji władze biora na siebie odpowiedzialność za to, że w czasie peregrynacji ujawni się brak poszanowania uczuć religijnych ludzi wierzących oraz pełnej wolności kultu. List kończy kolejna prośba kardynała o spowodowanie zwolnienia obrazu z Jasnej Góry ${ }^{35}$.

Prowadząc przygotowania do Nawiedzenia oraz starając się u władz o dopuszczenie obrazu Nawiedzenia do archidiecezji krakowskiej kard. K. Wojtyła we wrześniu 1967 r. nie przesądzał jaki będzie wynik jego starań. Przemawiając do duchownych, którzy mieli prowadzić misje poprzedzające Nawiedzenie, a z którymi spotkał się w gmachu krakowskiego seminarium duchownego w dniu 20 września 1967 r., stwierdził m.in. że niezależnie od tego „czy ten obraz przybędzie i ramy się zapełnią, czy też obraz nie przybędzie j ramy będą puste" parafia przeżywająca Nawiedzenie winna poczuć się częścią Kościoła powszechnego i odpowiedzialność za cały Kościół powszechny ${ }^{36}$.

Po raz kolejny kard. K. Wojtyła zabrał głos w sprawie zwolnienia kopii ikony jasnogórskiej w dniu 30 października 1967 r. Miało to miejsce na spotkaniu modlitewnym duchowieństwa archidiecezji krakowskiej w klasztorze oo. bernardynów

\footnotetext{
${ }^{34}$ AKMKr, AKKM, Teczka: Peregrynacja obrazu Matki Boskiej Częstochowskiej (pisma Episkopatu i Kurii przesłane do Władz Państwowych i odpowiedzi na te pisma), b.p. Pismo przewodniczqcego PRN m. Krakowa i przewodniczacego WRN w Krakowie do kard. K. Wojtyty z 26 X 1967 r:

${ }^{35}$ Tamże, b.p. Pismo kard. K. Wojtyty do preniera J. Cyrankiewicza z 28 X 1967 r; Odpis listu także: IPN Kr, syg. IPN Kr 039/27 t. 9, k. 248-249. Pismo kard. K. Wojtyly do J. Cyrankiewicza z 28 X 1967 r:

${ }^{36}$ Kard. K. W o j $\mathrm{t}$ y 1 a, Przemówienie wygłoszone $w$ czasie spotkania z misjonarzami w Seminarium Duchownym w Krakowie dnia 20 września 1967 r., [w:] Nawiedzenie obrazu Matki Bożej..., s. 10-11.
} 
w Kalwarii Zebrzydowskiej. Kard. K. Wojtyła poinformował księży, że otrzymał od władz wojewódzkich negatywną odpowiedź na prośbę o zwolnienie kopii obrazu Matki Bożej Częstochowskiej z Jasnej Góry i jej udział w peregrynacji na terenie archidiecezji ${ }^{37}$. W swym kazaniu wygłoszonym w czasie spotkania $\mathrm{z}$ kapłanami metropolita krakowski podkreślał zasługi diecezji katowickiej dla kontynuowania peregrynacji. $Z$ jednej strony biskupi śląscy, kapłani i wierni w każdym $z$ dekanatów występowali do władz o powrót obrazu na trasę peregrynacji, z drugiej - diecezja śląska nauczyła Kościół w Polsce „nowego «stylu» Nawiedzenia”. To właśnie w diecezji katowickiej uświadomiono sobie - mówił kardynał - że Nawiedzenie trwa pomimo pustych ram i że „Matka Boża jest!"38.

Zwracając się do duchowieństwa archidiecezji kardynał przestawił przebieg swoich starań o uwolnienie obrazu oraz motywy i argumenty jakimi posługiwał się w tych staraniach. Zaznaczył także, ze pomimo odmownej odpowiedzi na swą prośbę, którą otrzymał kilka dni wcześniej, jeszcze raz zwróci się do Prezesa Rady Ministrów. Metropolita krakowski stwierdził w Kalwarii Zebrzydowskiej:

„Jeżeli chodzi o nas, mamy i my już negatywną odpowiedź w tej sprawie. W swoim czasie bowiem wystapiłem z prośba, przedkładając właściwe racje; racje zreszta głębokie i zasadnicze, które płyna zarówno z poczucia naszej wolności religijnej i jej zasad, jak też iż poczucia dobrze zrozumiałego patriotyzmu. Bo przecież na pewno nie jest dobrze, z punktu widzenia naszej Ojczyzny, że obraz Matki Bożej Częstochowskiej - obraz Nawiedzenia - nie może być swobodnie, $z$ zachowaniem wszelkich wymagań porządku, widziany przez wiernych w poszczególnych parafiach, nie może być uczczony przez wiernych poszczególnych parafii, ale jest strzeżony na Jasnej Górze.

Występując więc do władz, miałem na myśli tę przede wszystkim okoliczność, że taki stan rzeczy jest jaką̧ś bolesną raną dla całego społeczeństwa, i że pragniemy się do zabliźnienia tej bolesnej rany przyczynić; usunąć nad wyraz dla nas przykry stan rzeczy, w którym widzimy obrazę naszej świętości, a w którym równocześnie zawiera się jakieś pogwałcenie, naruszenie uczuć religijnych ludzi wierzących - olbrzymiej wielkości w naszym narodzie - co z pewnością nie jest zgodne ani z przesłankami konstytucji, ani też z przesłankami autentycznej praworządności. Owszem, zwracając się w tej sprawie wyraźnie określiłem, że obraz Matki Bożej będzie do poszczególnych kościołów przewożony zamkniętym samochodem; że przywitanie i żegnane obrazu dokonywać się będzie w obrębie kościołów i miejsc sakralnych. Powiedziałem również, że dopuszczenie obrazu do naszej Archidiecezji, jego zwolnienie z Jasnej Góry, będzie dla nas dowodem i jakimś miernikiem wolności religijnej w naszym pań-

\footnotetext{
${ }^{37}$ IPN Kr, syg. IPN Kr 039/27 t. 10, k. 477. Meldunek informacyjny dot. przygotowań do peregrynacji ram obrazu M. B. Cz. na terenie parafii nowotarskich (2.11.1967).

${ }^{38}$ Kard. K. Wo j y l a, Kazanie wygloszone dla Kaplanów i Duszpasterzy' w Kalwarii Zebrzydonskiej, dnia 30 X 1967 r. [w] Nawiedzenie obrazu Matki Bożej..., s. 19-20.
} 
stwie, z której to wolności my chcemy korzystać z całym poszanowaniem dla porządku publicznego.

To wszystko powiedziałem: powiedziałem w imieniu Waszym i w imieniu przeszło półtora milionowej rzeszy wierzących w Archidiecezji; i to wszystko nie spotkało się ze zrozumieniem. W każdym razie odpowiedź, jaka otrzymałem we czwartek ub. tygodnia, podpisaną przez obu przewodniczących Wojewódzkiej Rady Narodowej oraz miasta Krakowa, jest odmowna.

Jednakże jeszcze raz zwróciłem się z tą sprawą do prezesa Rady Ministrów, przedstawiając mu, jeszcze gruntowniej, że właśnie racje: natury moralnej i natury społecznej..."39.

Pasterz archidiecezji krakowskiej nie mógł pominąc nieobecności obrazu Matki Bożej Częstochowskiej w czasie uroczystości rozpoczęcia Nawiedzenia (4 listopada 1967) w Nowym Targu. W swoim kazaniu kard. K. Wojtyła dziękował biskupowi H. Bednorzowi za „dziedzictwo maryjnego nawiedzenia”, które diecezja katowicka przekazała archidiecezji krakowskiej. Składając owe podziękowania metropolita krakowski starał się wyjaśnić zebranym jaki jest sens pustych ram:

„Stoimy wobec pustych ram i ja moi bracia i siostry nie mogłem przywieść wañi obrazu chociaż wszystko czyniłcm, ażeby do tego doprowadzić, a czyniłem w imię pokoju i poszanowania uczuć religijnych, w imię także poszanowania zasady wolności religijnej i tolerancji. Wszystko czyniłem, ażeby zrozumiano, ale racji przedłożonych nie przyjęto. I oto stoimy wobec pustych ram, lecz te ramy mają dla nas swoja wymowę, mają dla nas swoją bolesną wymowę, są cząstka naszego krzyża, ale wierzymy, że krzyż to jest wielkie dźwiganie w górę i w takiej postaci przekazujesz nam drogi arcypasterzu bratniej i siostrzanej diecezji śląskiej Nawiedzenie, w takiej postaci, w tych pustych ramach, a zarazem w tych pełnych ramach, w tych pełnych, pełnych Maryi, która na waszej śląskiej ziemi wśród olbrzymich trudów i przeciwieństw udowodniła, że jest wśród swego ludu"40.

Ciekawą opinię o postępowaniu i dzialaniach kard. K. Wojtyły w sprawie uwolnienia obrazu Matki Bożej Częstochowskiej z Jasnej Góry sformułował i na poczatku listopada 1967 r. przekazał SB ks. K. J. Był to duchowny z dekanatu orawskiego, który w czasie uroczystości w Nowym Targu obsługiwał magnetofony należące do Kurii Archidiecezjalnej, na które nagrywano całość uroczystości. W rozmowie z oficerem SB stwierdził on, że kard. K. Wojtyła poczuł się bardzo dotknięty decyzją władz świeckich. Księża, z którymi dyskutował ks. J. K., mieli powtarzać opinie, że „za cenę uwolnienia obrazu kardynał $\mathrm{K}$. Wojtyła mógłby wiele się wyrzec i całkowicie pójść na współpracę z władzami świeckimi - szkoda, że w tym czasie ktoś z tych władz nie dotarł do niego i nie wykorzystał dogodnej sytuacji. A warto było dogadać się z kard. Wojtyła, gdyż wśród kleru w Polsce i in-

${ }^{39}$ Tamże, k. 19-20.

${ }^{40}$ IPN Kr, syg. IPN Kr 039/27 t. 10, k. 361. Stenogram kazania wy'gloszonego przez kard. Wojtyte, w dniu 4 XI 67 r. podczas rozpoczecia peregrynacji w Nowym Targu. 
nych państwach coraz częściej mówi się, że jest on pewnym kandydatem na papieża w wypadku śmierci Pawła VI"41. Do poglądów ks. J. K. należy podchodzić ostrożnie. Jeżeli nawet takie opinie funkcjonowały wśród duchowieństwa krakowskiego, to nie były one powszechne. Jakoś nie chce się wierzyć, znając korespondencję kardynała krakowskiego z władzami i wydawane przez niego dokumentu oraz śledząc jego postępowanie wobec władz, aby tak łatwo mógł on przejść na pozycje ścisłej współpracy z władzami partyjno-państwowymi w $1967 \mathrm{r}$.

Już po rozpoczęciu peregrynacji $w$ parafiach archidiecezji krakowskiej, w dniu 11 listopada, kard. K. Wojtyła wydał komunikat skierowany do duchowieństwa i wiernych archidiecezji, który odczytano w kościołach i kaplicach archidiecezji w dniu 19 listopada. Poinformowano w nim wiernych, że mimo starań strony kościelnej nie udało się doprowadzić do zwolnienia kopii obrazu Matki Bożej Częstochowskiej z Jasnej Góry. Ponieważ jednak - jak to określono w komunikacie - „starania o zwolnienie obrazu „maja na celu podstawowe dobro życia społecznego", czyli poszanowanie uczuć osób wierzących oraz pełną wolność kultu, Kardynał zapowiedział, że nie zrezygnuje ze starań o dopuszczenie kopii obrazu jasnogórskiego do Nawiedzenia w parafiach archidiecezji. Pomimo nieobecności obrazu Królowej Polski, tak samo jak to miało miejsce na terenie diecezji katowickiej, ,ludzie wierzący przeżywają głęboko mimo pustych ram duchowa obecność Bogarodzicy" - głosił komunikat ${ }^{42}$.

Zgodnie z zapowiedzią wyrażoną w listopadowym komunikacie kard. K.Wojtyła w dniu 26 marca 1968 r. skierował dwa kolejne pisma: pierwsze do premiera J. Cyrankiewicza, drugie do J. Nagórzańskiego, przewodniczącego PWRN w Krakowie. Pismo do premiera J.Cyrankiewicza zostało skierowane przez kard. K. Wojtyłe w imieniu całego Episkopatu polskiego. W piśmie tym kardynał krakowski zwrócił uwagę, że choć przesłał pismo do premiera, do tej pory nie otrzymał od niego na nie odpowiedzi oraz wskazał, że peregrynacja ,która trwa już cztery miesiące ma charakter religijny i jako akt ściśle religijny jest związana $z$ miejscami sakralnymi. Kardynał pisał do premiera m.in. „Wszelkie próby (...) przedstawienia w fałszywym świetle Nawiedzenia - próby nie licujące z prawdziwym autorytetem władzy - nie potrafią jednakże w oczach wiernych zmienić właściwego odniesienia do tego głębokiego aktu religijnego, jakim jest nawiedzenie obrazu Matki Bożej Jasnogórskiej, nawet kiedy odbywa się bez obrazu, którego kopia przeznaczona do nawiedzenie polskich parafii i kościołów nadal jest strzeżona w klasztorze częstochowskim przez posterunki milicyjne". W niektórych parafiach, zwłaszcza na Podhalu, wierni stosują dawne zwyczaje, jak np. zbiorowe przechodzenia przy przejeżdżanie $\mathrm{z}$ parafii do parafii, ale $\mathrm{w}$ ten sposób wyrażają jedynie swe przekonania

${ }^{41}$ Tamże, syg. IPN Kr 039/27 t. 13, k. 522-523. Notatka slużbowa dot. rozmowy operacyjnej z kandydatem na t.w. ks. K.J. przeprowadzonej w driu 15 XI $67 \mathrm{r}$ w godz. 18.00-19.55.

${ }^{42}$ AKMKr, AKKM, Teczka: Peregrynacja obrazu Matki Boskiej Częstochowskiej (pisma Episkopatu i Kurii przesłane do Władz Państwowych i odpowiedzi na te pisma), b.p. Komunikat kard. K. Wojtył' "Do Duchowieńsfwa i Wiernych Archidiecezji Krakowskiej" z 11 XI 1967 r. 
i uczucia religijne. Pismo zawieraj kolejną prośbę o zwolnieni kopii obrazu Matki Bożej Częstochowskiej z Jasnej Góry: „W związku z tym ponownie zwracam się do Pana Premiera o spowodowanie zwolnienia kopii obrazu jasnogórskiego, aby mógł swobodnie nawiedzać parafie i kościoły w Archidiecezji Krakowskiej. Społeczeństwo katolickie, które w tylu już parafiach przejawiło prawdziwie dojrzała i godna postawę, przyjmie to $\mathrm{z}$ wdzięcznością jako dowód poszanowania swych przekonań i uczuć religijnych. Równocześnie zaś odpadnie niepotrzebny, a przy tym obrażający szerokie kręgi obywateli wierzących i społecznie szkodliwy wysiłek, polegający na stosowaniu insynuacji, którą władza i czynniki terenowe stale się posługują, że jest ona przeciwna prawu". Zaraz po prośbie o zwolnienie obrazu Nawiedzenia $z$ Jasnej Góry metropolita krakowski użył jeszcze jednego argumentu, który miał przekonać premiera do właściwej decyzji. Wierni w czasie peregrynacji zgodnie $\mathrm{z}$ intencjami Pawła VI modlą się o pokój i realizację sprawiedliwości w życiu współczesnego świata. Bolesnym nieporozumieniem więc - stwierdził kardynał - jest fakt, że ci którzy pragną prawdziwie pokoju i sprawiedliwości zgodnie ze swoją wiara „muszą tutaj stanąć oko w oko z przejawem niesprawiedliwości i naruszenia podstawowych praw człowieka w dziedzinie wolności religijnej”,43.

Natomiast list do przewodniczącego PWRN w Krakowie z marca 1968 r. zawierał protest przeciwko nadużyciem władzy, jakich dopuszczały się organy administracji terenowej. Księża proboszczowie i administratorzy parafii wzywani byli bowiem do przewodniczących powiatowych rad narodowych na rozmowy, w trakcie których przedstawiano im do podpisu tekst, iż Kuria Metropolitalna bez pozwolenia odpowiednich władz organizuje uroczystości Nawiedzenia oraz że uroczystości owe są organizowane jako manifestacje polityczne o charakterze antypaństwowym. Metropolita po raz kolejny zwracał władzom uwagę, że nie ubiegał się o pozwolenie na peregrynację, albowiem dokonuje się ona na terenie kościelnym. Kard. $\mathrm{K}$. Wojtyła zaprotestował także przeciwko groźbom, jakie stosowano wobec pracowników różnych instytucji i młodzieży szkolnej, odwodząc ich od udziału w uroczystościach Nawiedzenia. Groźby te zawierały sugestie zwolnienia z pracy lub kłopotów w szkole ${ }^{44}$.

W czasie Nawiedzenia kard. K.Wojtyła wykorzystywał każdą okazję, aby uświadomić i przypomnieć wiernym, duchowienstwu i władzom jakim gwałtem na wolności wyznania i sumienia jest fakt niedopuszczenia obrazu Nawiedzenia do archidiecezji krakowskiej. Głosząc kazanie na Jasnej Górze w czasie uroczystej sumy w dniu 3 maja 1968 r. do zgromadzonych pątników, którzy przybyli, aby oddać cześć Królowej Polski, metropolita krakowski powiedział m.in.:

\footnotetext{
${ }^{43}$ AAN, Ud/sW, syg. 82/9, k, 82-83. Pismo kard. K. Wojtvty do premiera J. Cyrankiewicza z 26 III $1968 \mathrm{r}:$

${ }^{44}$ AKMK, AKKM, b.p. Pismo kard. K. Wojtyty do przewodniczacego PWRN w Krakowie z 26 III $1968 \mathrm{l:}$
} 
„Teraz jeszcze pozwól Matko Boża Jasnogórska Królowo Polska, że powiem bardzo krótko o tym jak Ty odpowiadasz na nasze zawierzenia. Przez całe stulecia nasi przodkowie przychodzili tu na to miejsce, nawiedzali twoja jasnogórską stolicę, a Ty tutaj trwałaś, ale oto od 10 przeszło lat coś się zmieniło. Ty tu nie tylko trwasz, wyszłaś stąd. Ty tu nie tylko pozwalasz się nawiedzać pielgrzymom, sama nawiedzasz. Sama stałaś się pielgrzymem. To wszystko dowodzi jak bardzo głęboko trafiły do Twego serca słowa twojego Syna na krzyżu Oto Matka! Jak bardzo głęboko przyjęłaś Jego posłannictwo, posłannictwo miłości odwiecznej ojcowskiej i Boźej. Dlatego nas nawiedzasz, dlatego teź nawiedzasz archidiecezję krakowska, parafię po parafii kościół po kościele. My tutaj dzisiaj jesteśmy jako przedstawiciele archidiecezji krakowskiej, aźeby tutaj na Jasnej Górze podziękować Ci za to, że nas nawiedzasz. Żeby tutaj na Jasnej Górze także spojrzeć w Twoje oblicze, żeby popatrzeć na Twój obraz nawiedzenia, bo choć nas nawiedzasz, my nie możemy tam, w tych parafiach i kościołach patrzeć na Twój obraz nawiedzenia. Odebrano nam ten obraz, zamknięto go na Jasnej Górze, mimo wszystkich starań, mimo tłumaczeń, mimo przedłożeń wciąż trwa to zamknięcie, wciąż trwa to oddalenie obrazu, ale oddalenie obrazu nie jest twoja nieobecnością. Czujemy jak nas nawiedzasz w pustych ramach? Po czym to rozpoznajemy? Po tym, że gdy przychodzisz do którejkolwiek parafii przychodzi z Tobą miłość, miłość Twojego Syna, miłość przedwiecznego Ojca. Przychodzi z Tobą miłość dzięki której Syn Twój, który nazwał cię matka. I my nazywamy cię matką. Po tym rozpoznajemy twoje nawiedzenie. Puste ramy noszą, ale puste ramy nam ciebie nie odbieraja!!"45.

Do faktu nieobecności obrazu Matki Bożej kard. K.Wojtyła nawiązał także przemawiając w czasie uroczystości koronacji figury Najświętszej Maryi Panny w Piasecznie (pow. Tczew) w dniu 8 września 1968 r. W obecności arcybiskupa A. Baraniaka, 8 biskupów, ok. 150 księży i 20 tys. wiernych metropolita krakowski wyrażał ubolewanie, że wierni jego diecezji nie mogą oglądać cudownego obrazu, lecz pustą ramę, gdyż Matka Boża została uwięziona ${ }^{46}$.

Okazją do upomnienia się o prawa ludzi wierzących w archidiecezji krakowskiej w związku z akcją uwięzienia obrazu Nawiedzenia było dla kard. K. Wojtyły i innych biskupów krakowskich Nawiedzenie prawie każdej z parafii archidiecezji. W każdym wypadku, kiedy kardynał uczestniczył w rozpoczęciu lub zakończeniu peregrynacji w konkretnej parafii bardzo mocno akcentował brak obrazu Matki Bożej Częstochowskiej i konieczność wystawienia pustych ram. Przemawiając w dniu 3 marca 1968 r. w parafii św. Józefa w Krakowie - Grzegórzkach kard. K. Wojtyła stwierdził: „Mimo tego, że ramy obrazu są puste, to wszyscy duchowo odczuwamy obecność Matki Bożej z Częstochowy mimo, iż myślano, że wiara na-

\footnotetext{
${ }^{45}$ AAN, Ud/sW, syg. 82/9, k. 100-101. Stenogram kazania wyg toszonego przez bpa Wojtylę na Jasnej Górze w dniu 3 maja 1968 roku o godz. 11.30.

${ }^{46}$ Tamże, syg. 92/9, k. 130. Informacja MSW dla Urzędu d/s Wyznań z 9 IX $1968 \mathrm{r}$.
} 
sza w związku z tym osłabnie"47. Ten sam temat powrócił w wystapieniach biskupa krakowskiego w czasie Nawiedzenia parafii św. Józefa w Krakowie (7-8 IV 1968), kiedy to powiedział on m.in. że „Nawiedzenie odbywa się bez obrazu, co głęboko przeżywamy, a brak obrazu stanowi obrazę uczuć religijnych". W czasie uroczystości peregrynacyjnych w tejże parafii kard. $K$. Wojtyła dokonał odsłonięcia pustych ram umieszczonych w centralnej części kościola. W jednym ze swych kazań, „które wygłosił w sposób teatralno-dramatyczny", jak określiło to pracownik SB, kardynał wołał: „Boga nam chcą wydrzeć, ale Matka Boska Nieustającej Pomocy patronka tego kościoła nie dopuści do tego" ${ }^{48}$. Miesiąc później w trakcie Nawiedzenia parafii w Borku Fałęckim metropolita krakowski w swym kazaniu stwierdził: „czujemy się pokrzywdzeni, gdyż obrażono nasze uczucia religijne nie pozwalając na odwiedzenie nas przez Matkę Bożą z Częstochowy, jak to było dwa lata temu na Wawelu i Skałce, a w ubiegłym roku na Śląsku, ale jesteśmy dumnie, że nie ma jej na obrazie, ale jest w sercach wiernych"49. W czasie uroczystości zakończenia Nawiedzenia $w$ archidiecezji krakowskiej, która miała miejsce $w$ dniu 15 grudnia 1968 r. w Bazylice Mariackiej w Krakowie kard. K. Wojtyła przekazując Nawiedzenie do diecezji tarnowskiej podsumował swe starania o uwolnienie obrazu w sposób następujący: „Wyczerpaliśmy wszystkie środki, aby w czasie Nawiedzenia był obraz, a nie świeca. Może w diecezji tarnowskiej będzie inaczej”"50.

Do faktu nieobecności obrazu Matki Bożej Częstochowskiej w trakcie Nawiedzenia metropolita krakowski nawiązał ostatecznie w liście pasterskim, który skierował do wiernych swej archidiecezji z racji zakończenia Nawiedzenia. List ów odczytano w kościołach archidiecezji 24 listopada 1968 r. Nawiązując do uroczystości milenijnych, jakie miały miejsce na Wawelu w 1966 r., kard. K. Wojtyła. opisując nastrój i uczucia tamtej uroczystości, stwierdził, iż „wówczas też z katedry wawelskiej myśl nasza biegła do tych wszystkich kościołów i parafii Archidiecezji, których katedra jest matką. Matka-Katedra prosiła Matkę Boga o nawiedzenie ich wszystkich. Prosiła o to, aby Matka Chrystusowa ujęła w swoje niewidzialne, a przecież wciąż czynne dłonie światło Chrztu i wniosła na progu nowego tysiąclecia do wszystkich parafii i do wszystkich dusz. Wobec niej pragnęliśmy odnowić przyrzeczenia Chrztu Świętego, które wyznaczają drogi chrześcijańskiego życia na ziemi i jej oddawać na własność naszą dobrą wolę trwania w Jezusie Chrystusie

${ }^{47}$ IPN Kr, syg. IPN Kr 039/27 t. 10, k. 726. Informacja na temat przebiegu uroczystości peregrynacyjnych na terenie parafii m. Krakowa w okresie marzec - kwiecień $1968 \mathrm{r}$. (Kraków, I3 IV 1968).

${ }^{48}$ AAN, Ud/sW, syg. 82/38, k. 33. Informacja z przebiegu peregrynacji na terenie m. Krakowa (Kraków, 13 IV 1968); IPN Kr, syg. IPN Kr 039/27 t. 9, k. 646-648. Informacja dotyczqca przebiegu uroczystości peregrynacyjnych w parafii m. Krakowa $w$ okresie od marca do maja 1968 : (Kraków, maj 1968).

49 IPN Kr, syg. IPN Kr 039/27 t. 9, k. 646-648. Informacja dotyczqca przebiegu uroczystości peregrynacyjych w parafii m. Krakowa w okresie od marca do maja $1968 \mathrm{r}$. (Kraków, maj 1968).

${ }^{50} \mathrm{AAN}, \mathrm{Ud} / \mathrm{sW}$, syg. 82/9, k. 147. Informacja MSW dla Urzędu d/s Wrznań z 16 XII $1968 \mathrm{r}$. 
oraz w Jego Kościele wśród nowych czasów"51. W opinii kard. K. Wojtyły, owa prośba wyrażona w dniu uroczystości milenijnych w Krakowie została spełniona. „Wprawdzie - jak stwierdził arcybiskup krakowski - do kościołów i parafii Archidiecezji Matka Jasnogórska nie mogła przybyć w swoim wizerunku, lecz niemniej przybyła w sposób sobie właściwy, czemu nawet zakaz nawiedzenia obrazu nie mógł przeszkodzić!” i dodał: „Dzisiaj przy końcu roku nawiedzenia możemy to z całym pokryciem stwierdzić. Matki Bożej nie było wśród nas w obrazie jasnogórskim - ale Matka Boża była wśród nas macierzyńskim nawiedzeniem swego ducha"s2.

\section{DUCHOWNI I WIERNI WOBEC FAKTU NIEOBECNOŚI KOPII OBRAZU MATKI BOŻEJ W CZASIE NAWIEDZENIA}

W okresie przygotowań do peregrynacji obrazu Matki Bożej Częstochowskiej po parafiach archidiecezji krakowskiej temat obecności kopii tego obrazu w czasie Nawiedzenia lub jego braku stanowił jeden z podstawowych problemów zajmujących duchowieństwo i wiernych. Wiele osób komentowało fakt uwięzienia obrazu na Jasnej Górze i zastanawiało się, czy władze pójdą na rękę kard. K. Wojtyle dopuszczając obraz Nawiedzenia do archidiecezji. SB dokładnie wszystkie owe opinie i komentarze zbierała za pomocą swych źródeł informacji i odnotowywała.

Od sierpnia do października 1967 r. wśród duchowieństwa archidiecezji panował znaczny optymizm odnośnie zwolnienia kopii ikony jasnogórskiej. W sierpniu 1967 r. wśród duchownych dominował pogląd, że peregrynacja będzie odbywała się z udziałem obrazu jasnogórskiego. Miało to stanowić wbicie klina pomiędzy Wojtyłę i Wyszyńskiego ${ }^{53}$. W październiku padały stwierdzenia, że „,władze uwolnią go [obraz Nawiedzenia - M.T.] z Jasnej Góry i dadzą kard. Wojtyle"54. Proboszczowie i delegaci duchowieństwa z powiatu nowotarskiego, gdzie miało się rozpocząc Nawiedzenie, zebrani na spotkaniu w dniu 6 października 1967 r. w Szaflarach, także dyskutowali na powyższy temat. Wielu z nich było zdania, że władze nie będą przeszkadzały w peregrynacji, albowiem kard. K. Wojtyła nawiązał „przyjemny dialog korespondencyjny" z premierem J. Cyrankiewiczem oraz sekretarzem KW PZPR w Krakowie Czesławem Domagała. W ich opinii władze świeckie miały bardzo dobrą opinie o metropolicie krakowskim ${ }^{55}$.

${ }^{51}$ Tamże, syg. 82/38, k. 75. List Pasterski na zakończenie peregrynacji Matki Bożej Jasnogórskiej w naszej archidiecezji (Kraków, 13 XI $1968 \mathrm{r}$.).

${ }^{52}$ Tamże, k. 75-76.

${ }^{53}$ IPN Kr, IPN Kr 039/27 t. 9, k. 225. Informacja dotyczqca przygotowań do peregrynacji kopii obrazu MBCz. w archidiecezji krakowskiej (30 VIII 1967).

${ }^{54}$ Tamże, syg. IPN Kr 039/27 t. 10, k. 467. Wyciqg z doniesienia t.w. ps. „Tuz” z dnia 24 X 1967 r.

${ }_{55}$ Tamże, syg. IPN Kr 039/27 t. 13, k. 441. Meldunek informacyjny Komendy Wojewódzkiej MO w Nowym Targu dot. przygotowań kleru do peregrynacji obrazu M.B. Czestochowskiej (Nowy Targ, 14 X 1967). 
Część księży była tak pewna wydania przez władze zezwolenia na udział obrazu Matki Bożej w nawiedzeniu, że byli gotowi jechać na Jasną Górę i stamtąd przywieźć go do Nowego Targu. Z propozycją taka miał wystapić do kard. K. Wojtyły proboszcz parafii nowotarskiej ks. Marian Stawarz. Argumentował on, że władze zdjęły posterunki milicyjne ustawione wokół klasztoru jasnogórskiego, co pozwoliłoby zabrać obraz, a stronie państwowej wyjść ze „ślepego zaułku”. Kard. K. Wojtyła miał nie zgodzić się na ową akcję wierząc, że jego prośba skierowana do premiera J. Cyrankiewicza załatwi sprawę w sposób legalny ${ }^{56}$.

T.w. SB o pseudonimie „Tuz” informował SB w październiku 1967 r., że wśród duchowieństwa i osób świeckich istnieje duże zainteresowanie peregrynacją. Najczęściej stawianym pytaniem przez wiernych, było pytanie o to, czy kopia obrazu zostanie zwolniona $z$ Jasnej Góry. W czasie dyskusji na ten temat bardzo często pada stwierdzenie, że za zatrzymanie obrazu na terenie diecezji katowickiej ponosi odpowiedzialność Edward Gierek. Uważano, że to on podjął decyzję o zatrzymaniu delegacji przewożącej obraz z Częstochowy do Katowic ${ }^{57}$.

Jeżeli nawet wyrażano nadzieję na to, że obraz Matki Bożej nawiedzi archidiecezję krakowską, to zastanawiano się także nad tym, co zrobić gdy tego obrazu zabraknie. Cześć duchowieństwa wyrażała zdanic, że nic nalcży prowadzić peregrynacji bez obrazu. Inni uważali, że wzorem diecezji katowickiej należy wystawiać puste ramy. Padały także propozycje, że przecież w każdej z parafii jest kopia obrazu częstochowskiego. Może więc należałoby wykorzystać do Nawiedzenia ów wizerunek $?^{58}$.

Rozpoczęcie Nawiedzenia w archidiecezji krakowskiej nastapiło 4 listopada 1967 r. w Nowym Targu. W czasie przygotowań do tego wydarzenia bp Jan Pietraszko spotykając się z duchownymi pobliskich parafii naciskał na to, aby ci z ambon utwierdzali wiernych $w$ przekonaniu, że władze świeckie zezwolą na peregrynację obrazu Matki Bożej Częstochowskiej. Swą nadzieję w tej kwestii opierał on na przekonaniu, że „kard. K. Wojtyła upokorzył się” i zwrócił się z prośbą do Przewodniczącego Prezydium WRN o zgodę na zwolnienie obrazu z Jasnej Góry ${ }^{59}$.

Na początku listopada 1967 r., po oświadczeniu kard. K. Wojtyły, jakie złożył on na spotkaniu z duchowieństwem archidiecezji w Kalwarii Zebrzydowskiej, ogół księży był przekonany, że władze nie wydadzą zezwolenia na peregrynacje kopii obrazu Matki Bożej Częstochowskiej. Powszechnie wyrażano ubolewania nad tym faktem. Wielu księży wyrażało opinie, że gdyby władze wydały taką opinię ,łagodziło by to sytuację i znalazło właściwy oddźwięk w społeczeństwie", a postawa władz wywołuje wręcz odwrotny skutek i wywołuje wrażenie, iż w Polsce nie ma wolności kultu religijnego. Tylko nieliczni duchowni wyrażali opinię, że należy za-

${ }^{56}$ Tamże, syg. IPN Kr 039/27 t. 13, k. 522. Notatka stużbowa dot. rozmowy operacyjnej z kandydatem na t.w. ks. K. I. przeprowadzonej w dniu 15 XI $67 \mathrm{r}$. w godz. od 18.00-19.55.

${ }^{57}$ Tamże, syg. IPN Kr 039/27 t. 10, k. 467. Wyciag z doniesienia t.w. ps. ,Tuz” z dn. 24 X 1967 r.

${ }^{58}$ Tamże.

${ }^{59}$ Tarnże, syg. IPN Kr 039/27 t. 10, k. 460. Meldunek informacyjny dot. przygotowań do peregrynacji ram obrazu $M B C z$ na terenie pow. Nowy Targ (30 X 1967 r.). 
przestać tego rodzaju imprez jak peregrynacja i „,sprowadzić pracę kościoła do właściwych form i ram". Ci sami duchowni wydawali opinię, iż ogół księży jest zmęczony licznymi uroczystościami w roku milenijnym ${ }^{60}$. Jak zaznaczono $w$ jednym ze sprawozdań dotyczących peregrynacji „w tym stanie rzeczy daje się jeszcze zauważyć moment oczekiwania, że Premier Cyrankiewicz może zmienić decyzję władz wojewódzkich"61.

Zarówno w czasie przygotowań do Nawiedzenia, jak i w trakcie jego trwania nieznaczna cześć duchownych była przeciwna wystawianiu pustych ram w czasie trwania uroczystości peregrynacyjnych. Uważali oni, że należy w centralnym miejscu w ołtarzu ustawić statuę lub obraz Matki Bożej. Zdarzały się przypadki, że księża owi po rozmowach z władzami administracyjnymi wystawiali ramę. Jeden z proboszczów parafii krakowskiej skłonny był nie wystawiać pustych ram do chwili, kiedy go nie poproszono na rozmowę do przewodniczacego rady narodowej i nie zabroniono mu takiego postępowania. Rozmowa spowodował, że ,w ostatnim momencie zmuszony był sklecić prowizoryczną ramę i wystawić ją". Podobnie było i w kilku innych parafiach ${ }^{62}$.

W dokumentach SB można odnaleźć także informacje o zastrzeżeniach jakie wysuwały osoby świeckie, głownie ze środowisk inteligencji, wobec koncepcji prezentowania pustych ram w czasie Nawiedzenia. W Krakowie pojawiały się głosy, iż taka idea peregrynacji jest po trosze zabobonem i śmieszne jest, aby oddawać cześć drzewu. Wśród tych opinii była i tak, że już w przeszłości Kościoła podobnego typu zachowania doprowadziły do obrazoburstwa ${ }^{63}$. Należy uznać, że były to jednak opinie odosobnione i wyrażane przez osoby, które nie rozumiały znaczenia symbolu pustych ram, a także chyba miały dość idealistyczny obraz relacji Kościoła - państwo ludowe.

Problem obecności bądź nieobecności obrazu Nawiedzenia pojawiał się co rusz w czasie przygotowań duszpasterskich do peregrynacji. Zakładając, że obraz nie zostanie wpuszczony przez władze na teren archidiecezji w założeniach duszpasterskich Nawiedzenia polecono duszpasterzom, aby w czasie modlitw przygotowujących parafie do uroczystości nie zapominali także o intencji ,aby znakiem Nawiedzenia naszej parafii przez Matkę Bożą był Jej obraz Jasnogórski, w którym nawiedzała juz 10 diecezji" "44.

Planując przebieg Doby Nawiedzenia w każdej z parafii przygotowywano się zarówno do sytuacji, kiedy obraz Nawiedzenia będzie obecny, jak też gdy w jego

\footnotetext{
${ }^{60}$ Tamże, syg. IPN Kr 039/27 t. 10, k. 494. Informacja na temat przygotowań do peregrynacji ram obrazu MB Częstochowskiej w Zakopanym (3 XI 1967).

${ }^{61}$ Tamże.

${ }^{62}$ Tamże, syg. IPN Kr 039/27 t. 10, k. 731. Wyciag z notatki stużbowej t.w. „Janek” z dnia 19 IV 1968 r. pozostajacego na kontakcie por: M. Swiqtka (19 IV 1968).

${ }_{63}$ Tamże, syg. IPN Kr 039/27 t. 10, k, 450. Wyciag z doniesienie t.w. „Carmen” z dnia 18 pażdziernika $1967 \mathrm{r}$.

${ }^{64}$ Co chcemy osiagnać $w$ duszpasterstwie przez Nawiedzenie? (Glówne zatożenia duszpasterskie zwiazane z nawiedzeniem), [w:] Nawiedzenie obrazu Matki Bożej..., s. 30.
} 
miejsce trzeba będzie umieścić pustą ramę. W zaleceniach duszpasterskich dla duchowieństwa Kuria Metropolitalna w Krakowie poleciła umieścić obraz Nawiedzenia na naczelnym miejscu w każdym z kościołów. Dla obrazu należało przygotować tron na głównym ołtarzu kościoła i na ołtarzu polowym. Duszpasterzom zwrócono uwagę na fakt, że ze względu na wagę obrazu $(80 \mathrm{~kg})$ muszą one być bardzo solidne. Jednocześnie $w$ powyższych zaleceniach uprzedzono duchowieństwo, że w wypadku nieobecności obrazu Matki Bożej należy przygotować na ołtarzu głównym w kościele i na ołtarzu polowym pustą ramę. Rama owa stanowiła jedynie element dekoracyjny. Wyraźnie władze kościelne stwierdzały, że z tej racji nie wolno jej nosić w procesjach ${ }^{65}$.

Z powodu niewyjaśnionej do końca sytuacji obecności obrazu w czasie Nawiedzenia kolejnych parafii władze diecezjalne opracowując materiały duszpasterskie na ową uroczystość sporządziły dwie wersje powitania Nawiedzenia w parafii. Jedną na wypadek obecności obrazu Matki Bożej Częstochowskiej, druga - na powitanie Nawiedzenie, gdyby obrazu nie było ${ }^{66}$.

Do początków listopada 1967 r. jedynie dyskutowano o nieobecności kopii obrazu Matki Bożej Częstochowskiej w czasie peregrynacji w archidiecezji krakuwskiej. W dniu 4 listopada 1967 r. w Nowym Targu peregrynacja się rozpoczęła. Nie sposób było, aby nieobecności obrazu Nawiedzenie nie zauważyć i nie odnieść się do owego faktu, który potwierdzał prześladowania Kościoła $\mathbf{i}$ wiary w Polsce. Prawie wszystkie osoby zabierający głos w czasie tej uroczystości mówiły o fakcie nieobecności obrazu Nawiedzenia oraz podkreślały, że pomimo tego Matka Boża rzeczywiście jest obecna w swoim Nawiedzeniu i rzeczywiście nawiedza parafie ziemi krakowskiej i Podhala. Biskup katowicki Herbert Bednorz, w którego diecezji Nawiedzenie dopiero co się zakończyło, tak mówił o jego owocach, które wydało mimo nieobecności cudownego obrazu:

„I gdy Nawiedzenie maryjne Królowej Polski na Śląsku się odbywało, ludność wierzy, że Maryja była z nim, choć nieobecny był obraz Matki Boskiej Częstochowskiej. Został on we wrześniu ubiegłego roku zatrzymany w lesie pod Będzinem, odtransportowany na Jasną Górę, tak, że dzisiaj nie mogliśmy go wam tutaj przekazać. Gdy na Śląsku odbywaliśmy nabożeństwo Nawiedzenia maryjnego nadprzyrodzony zmysł nam mówił, naszemu prostemu roboczemu ludowi, że choć oczy jego nie widziały obrazu Pani Jasnogórskiej, dostrzegały tylko pustą ramę, to nie mniej lud nasz wierzył, że Maryja była z nim. Dzięki temu kult maryjny rozwijał się znakomicie w całej diecezji, we wszystkich parafiach, we wszystkich dekanatach. Jeszcze nigdy nie był on tak żywy i tak widoczny jak w czasie nabożeństwa Nawiedzenia Matki Bożej. O tym nie zapomnijmy, że Maryja była z nami i będzie $\mathrm{z}$ nami jeśli jej tylko pozostaniemy wierni. $\mathrm{Z}$ całego serca życzę wam, wszystkim tu tak licznie zgromadzonym, całej archidiecezji krakowskiej podobnego przeży-

\footnotetext{
${ }^{65}$ Tamże, k. 41.

${ }^{66}$ Tamże, k. 43-45.
} 
cia, błogosławionej bliskości Najświętszej Maryi Panny Królowej Polski. Może ono stać się waszym udziałem, choć patrzeć będziecie tylko na pustą ramę, jak to teraz w Nowym Targu się dzieje. O to będziemy się modlili" "67.

Kard. Stefan Wyszyński w Nowym Targu mówił o bólu jaki powoduje nieobecność oblicza Matki Bożej wśród wiernych, a także o niesprawiedliwości jaka spotyka wszystkich wierzących mieszkańców archidiecezji, a szczególnie pielgrzymów, którzy zdążając do Nowego Targu byli prześladowani przez siły milicyjne. Odnosząc się do hucznie obchodzonej właśnie przez władze 50. rocznicy wybuchu Wielkiej Socjalistycznej Rewolucji Październikowej Prymas mówił, że osoby wierzące ze zrozumieniem odnoszą się do tych obchodów, ale te same osoby mają prawo, aby i ich prawa szanować. Uznając, że dzieje się niesprawiedliwość Prymas Tysiąclecia wzywał jedynie wiernych do postawy jedności, pokoju i przebaczenia. Zwracając się do kard. K. Wojtyły i wiernych archidiecezji krakowskiej Prymas mówil:

„To też ból twój najdostojniejszy księże kardynale, metropolito my wszyscy podzielamy. Podzielamy i wasz ból dzieci najmilsze, tym bardziej, że jej skromne i ciche oblicze jest tak życzliwe i pełne miłości dla wszystkich. Przewędrowała w tym wieńcu nawiedzeń ogromny szmat ojczyzny naszej, poprzez wschodnie jej i północne i zachodnie rubieże, opasując płaszczem i ramionami swej miłości ubezpieczając Polskę, choć przecież dana jest ku obronie narodu naszego. Gdy dalej prowadzi swą wędrówkę po południowych rubieżach Rzeczypospolitej, tak byłoby rzeczą zrozumiała, słuszna, było by wyrazem i znakiem wewnętrznej wolności Kościoła, sumienia i prawa do publicznej czci, gdyby stanęła tutaj ze swoim słodkim obliczem wśród nas"68.

Ks. Marian Stawarz, proboszcz parafii w Nowym Targu witając Nawiedzenie w swojej parafii, mówił: „Nie ma jej tu wizerunku [Matki Bożej], bo go nie wpuszczono na krakowską ziemię, ale ona jest z nami" ${ }^{\prime \prime 69}$.

Zgodnie z zaleceniami władz diecezjalnych księża przygotowując uroczystości Nawiedzenia w sposób szczególny eksponowali puste ramy. Do rzadkości należały przypadki, że owych ram nie było. Na 13 parafii miasta Krakowa, w których odbywała się peregrynacja od marca do maja 1968 r., tylko w trzech (św. Kazimierza, św. Józefa i na Prokocimiu) nie było wystawionych ram. W pozostałych $10 \mathrm{pa-}$ rafiach ramy były i to dekorowane w rożny sposób. W Nowej Hucie - Bieńczycach wewnątrz ramy umieszczono cierniowa koronę na tle wstęgi o barwach narodo-

${ }^{67}$ IPN Kr 039/27 t. 10, k. 357-358. Stenogran kazania wygtoszonego przez bp. Bednorza, w dniu 4 XI 67 r. podczas rozpoczęcia peregrynacji w Nowyn Targu.

${ }_{68}^{6}$ Tamże, syg. IPN Kr 039/27 t. 13, k. 366. Stenogram kazania kard. Wyszyńskiego, wygłoszonego w Nowym Targu w dniu 4 XI $67 \mathrm{r}$, na uroczystości inauguracji peregrynacji w archidiecezji krakowskiej.

${ }^{69}$ Tamże, syg. IPN Kr 039/27 t. 10, k. 356. Stenogram kazania wygłoszonego przez ks. Stawarza w dniu 4 XI 67 r: podczas rozpoczęcia peregrynacji w Nowym Targu. 
wych. Całość ramy oświetlona była przez reflektory. W parafii Pychowice rama po obrazie matki Bożej została zapełniona symbolem więziennej kraty ${ }^{70}$.

Problem pustych ram po obrazie Matki Bożej poruszano w rozmowach profilaktycznych prowadzonych przez władze z osobami duchownymi. Na dzień 29 października 1967 r. na rozmowę taką do przewodniczącego Powiatowej Rady Narodowej w Nowym Targu wezwany został ks. Leonard Harędziański, proboszcz parafii w Ludźmierzu. Przewodniczący PRN wypytywał go m.in. o kwestię organizacji Nawiedzenia w parafii ludźmierskiej. Od proboszcza uzyskał informację, że zgodnie z poleceniem hierarchii kościelnej w kościołach w miejsce obrazu Matki Bożej będą wystawiane puste ramy, które każdy z proboszczów wykona we własnym zakresie. Z parafii do parafii nie będą przewożone żadne symbole religijne. Proboszcz parafii ,żegnającej" Nawiedzenia uda się wraz delegacją wiernych do kolejnej parafii, która będzie przeżywać Nawiedzenie i tam zapali świece ustawioną obok pustej ramy. Ks. L.Harędziański w rozmowie z urzędnikiem PRN wyraził nadzieję, że obraz Matki Bożej Częstochowskiej nawiedzi jednak parafii archidiecezji. Nadzieje swoja opierał duchowny na fakcie, iż kard. K. Wojtyła ponownie wystosował w tej sprawie list do premiera J. Cyrankiewicza ${ }^{71}$.

W 1968 r. na rozmowe do Dzielnicowej Rady Narodowej Kraków - Stare Miasto wezwany został administrator parafii Bożego Ciała w Krakowie ks. Franciszek Grabiszewski. Oczekiwali na niego zarówno przewodniczący DRN, jak i kierownik wydziału spraw wewnętrznych owej rady. Wypytywali się oni ks. F. Grabiszewskiego o to, w jaki sposób zostanie przeprowadzona peregrynacja w jego parafii. Szczególnie zaś interesowała ich kwestia eksponowania pustej ramy. Prosił on księdza administratora, aby owe ramy „,nie były rażąco widoczne, jak w Prądniku Czerwonym i u św. Katarzyny” oraz „nie wpadały zbytnio w oczy” "72.

W szczególny sposób nieobecność obrazu w swoich wystapieniach podczas uroczystości peregrynacyjnych podkreślał biskup sufragan J. Groblicki. Temat obrazu pojawił się chociażby w rozmowie jaką przeprowadził biskup sufragan z przewodniczącym PWRN w Krakowie J. Nagórzańskim w dniu 22 listopada 1967 r. Na zakończenie spotkania, które dotyczyło zarówno przebiegu Nawiedzenia w powiatach nowotarskimi oraz zakopiańskim, jak i wystąpień biskupa J. Groblickiego, ten zadał pytanie przewodniczącemu J. Nagórzańskiemu: „A teraz Panie Przewodniczący to co jest najważniejsze dla naszego Kardynała, chciałbym się dowiedzieć co z tym obrazem będzie? Przez dwie godziny co to będę ukrywał zbierał od panów łajanie, może na zakończenie jakaś pociecha dla nas, może jakaś weselsza nowina

${ }^{70}$ Tamże, syg. IPN $\mathrm{Kr} 039 / 27$ t. 9, k. 647, 651. Informacja dotyczqaca przebiegu uroczystości peregrynacyjnych w parafiach m. Krakowa w okresie od marca do maja $1968 \mathrm{r}$ :

${ }^{71}$ Tamże, syg. IPN Kr 039/27 t. 10, k. 468-469. Meldunek informacyjny dotyczacy przy'gorowań do peregrynacji w Nowym Targu (31 X 1967 r.).

${ }_{72}$ AKMK, KKMK, Teczka: Peregrynacja obrazu Matki Boskiej Częstochowskiej (sprawozdania z poszczególnych dekanatów dotyczące trudności w przeprowadzeniu peregrynacji w parafiach), b.p. Notatka ks. F. Grabiszewskiego z 9 X 1968 r. 
dla ks. Kardynała. Niech Pan Przewodniczący zmieni stanowisko, byłoby to dla naszego Kardynała wielką radością i byłby za to wdzięczny. Możemy mieć jakąś nadzieję?". Przewodniczący odpowiedział jedynie, że stanowisko władz w powyższej kwestii nie uległo zmianie ${ }^{73}$.

W kolejnych kazaniach biskupa pojawiały się informacje o uwięzieniu obrazu Matki Bożej Częstochowskiej. Przypominał on nieustannie, podobnie jak kard. K. Wojtyła, że fakt zatrzymania kopii obrazu na Jasnej Górze stanowi „brutalne pogwałcenie uczuć religijnych i godności wiernych"74. W swoim wystapieniu w Rabie Wyżnej (5 XI 1967) bp J. Groblicki stwierdził, że władze świeckie przeszkadzają w peregrynacji, co jest działalnością skierowaną przeciwko Kościołowi ${ }^{75}$. W parafii św. Katarzyny w Krakowie powiedział on: „wiszą nad nami puste ramy. Jest to dowód bolesnego uszczuplenia prawa Kościoła, dowód naruszenia praw zagwarantowanych przez najwyższe ustawy. Obok jest napis: „A jednak jesteś $\mathrm{z}$ nami. Oddaje on dobrze stan faktyczny". W dniu następnym, tj. 12 maja, w parafii na Płaszowie powiedział zaś: „Puste ramy napawaja nas smutkiem, ale puste ramy nie są puste, gdyż są wypełnione tysiącami serc kochających Matkę Boża"”76.

O uwolnienie obrazu z Jasnej Góry oprócz kardynała i biskupów krakowskich zwracali się do władz także $i$ inni duchowni archidiecezji. Charakterystyczna jest tu np. akcja podjęta przez duchowieństwo dekanatu orawskiego. W dniu $10 \mathrm{czerw}$ ca 1968 r., czyli na dwa miesiące przed mającą się odbyć na Orawie peregrynacją, księża z owego dekanatu skierowali do premiera J. Cyrankiewicza petycję w imieniu swoim własnym oraz całego Ludu Orawskiego o zezwolenie na pielgrzymkę kopii obrazu Matki Bożej Częstochowskiej. Pismo owo podpisali: ks. Józef Buroń, dziekan dekanatu i proboszcz parafii Lipnica Mała, ks. Julian Łysek, wicedziekan i rezydent w parafii Jabłonka Orawska, ks. Józef Czekaj, proboszcz parafii Podwilk, ks. Franciszek Szymonek, proboszcz parafii Zubrzyca Górna, o. Franciszek Gerard Soprych, rezydent w parafii Chyżne, ks. Tadeusz Masny, wikariusz ekonom ad interim parafii Jabłonka Orawska i ks. Edward Piekarz, wikariusz parafii Lipnica Mała ${ }^{77}$. Wyżej wymienieni księża zwrócili się do władz z następująca prośbą:

\footnotetext{
${ }^{73}$ Tamże, syg. IPN Kr 039/27 t. 13, k. 559. Notatka z przeprowadzonej rozmowy z ks. biskupem Groblickim Julianem wikariuszem generalnym Kurii Metropolitalnej w Krakowie przez Przewodniczqcego Prezydium WRN tow. J. Nagórzaniskiego w dniu 22 XI $1967 \mathrm{r}$.

${ }^{74}$ AAN, Ud/sW, syg. 82/9, k. 102. Notatka MSW dla Urzędu d/s Wyznań z 8 V 1968 r.

${ }^{75}$ IPN Kr, syg. IPN Kr 039/27 t. 13, k. 491. Pismo Urzędu Spraw Wewnętrznych PWRN w Krakowie do MSW 7 XI $1967 \mathrm{r}$.

${ }^{76}$ IPN Kr, syg. IPN Kr 039/27 t. 9, k. 650. Informacja dotyczqca przebiegu uroczustości peregrynacyjnych w parafiach $m$. Krakowa w okresie od marca do maja $1968 \mathrm{r}$.

${ }^{77}$ AAN, Ud/sW,syg. 82/38, k. 61. Podpisy duchownych pod dokumentem różnią się $w$ kilu przypadkach od imion i nazwisk księży pracujących w dekanacie orawskim w 1968 r., np. pismo podpisal ks. Sławomir Sopruch, a ksiądz o takim imieniu i nazwisku nie pracował wówczas w archidiecezji krakowskiej. Zmiana imienia lub przekręcenie nazwisk mogło być celowym wybiegiem, w celu zmylenia władz, jeżeli te chciałyby zastosować represje wobec podpisujących petycję.
} 
„W imieniu Ludu Orawskiego i naszym zwracamy się z uprzejmą prośbą o udzielenie zezwolenia na pielgrzymkę Kopii Obrazu Matki Boskiej Częstochowskiej po ziemi Orawskiej, leżącej na rubieżach Rzeczypospolitej Polski Ludowej w dniach od $3^{\mathrm{g} o}$ do $12^{\text {go }}$ sierpnia bieżącego roku. Przychylne i życzliwe załatwienie prośby Ludu Orawskiego przyczyni się do jeszcze silniejszego związania z Ojczyzną. W latach plebiscytu po pierwszej wojnie światowej Lud Orawy przyłączył się do Polski w zaufaniu pełnej swobody praktyk religijnych, której wyrazem byłaby rzeczywistość Kopii Obrazu Matki Boskiej Częstochowskiej na Jego ziemi" "78.

Fakt nieobecności obrazu Matki Bożej Częstochowskiej w czasie uroczystości peregrynacyjnych wywoływał oburzenie i rozżalenie wiernych. Ich reakcje były bardzo różne: wysyłano delegacje, pisano protesty i petycje do władz, modlono się o uwolnienie obrazu. Jako pierwsi na nieobecność kopii ikony z Jasnej Góry w archidiecezji zareagowali górale z Podhala, albowiem od tego rejonu rozpoczęło się Nawiedzenie w archidiecezji krakowskiej.

W dniu 28 października 1967 r. w parafii w Białce Tatrzańskiej odbywał się odpust. Wzięło w nim udział ok. 15 duchownych z parafii dekanatów nowotarskiego i zakopiańskiego. Wśród nich by1 i tajny współpracownik SB o pscudonimie „Rzepa”. To on zdając relacje z przebiegu uroczystości odpustowej poinformował władze, iż z Podhala może do Warszawy wyruszyć delegacja górali, którzy będą starali się dotrzeć do premiera J.Cyrankiewicza. Celem delegacji miało być uzyskanie zgody na zwolnienie obrazu Matki Bożej Częstochowskiej z Jasnej Góry i jej udział w uroczystościach peregrynacyjnych na terenie Podhala. Jako źródło swej informacji t.w. „Rzepa” wskazał ks. Leona Krejczego z Szaflar. Delegacja górali miała wyruszyć 29 października, a miał jej przewodniczyć Adam Pach, ludowy poeta i członek Związku Podhalan. Oczywiście Referat Służby Bezpieczeństwa w Nowym Targu wdrożył procedury mające na celu ustalenie listy członków domniemanej delegacji ${ }^{79}$.

Jednak do 3 listopada 1967 r. SB nie stwierdziło, aby z terenu Zakopanego były wysyłane petycje lub organizowane delegacje do władz wojewódzkich lub centralnych w sprawie zezwolenia na peregrynację. Uzyskano jedynie niesprawdzoną informację, iż z terenu Miętustwa w końcu października wyjechała jakaś grupa osób w tym właśnie celu. Miała ona dotrzeć do Urzędu ds. Wyznań w Warszawie. Tam miano oświadczyć członkom delegacji, aby wracali spokojnie, gdyż „wszystko będzie po ich myśli" 80 .

SB posiadało jednak prawdziwe informacje. $Z$ terenu Podhala organizowana była w tym czasie delegacja wiernych, która udała do Prezydium WRN w Krako-

\footnotetext{
${ }^{78}$ Tamże, k. 61.

${ }^{79}$ IPN Kr, syg. IPN Kr 039/27 t. 10, s. 461. Meldunek informacyjny dot. przygotowań do peregrynacji ram obrazu M.B.Cz. na terenie powiatu Nowy Targ (30.10.1967).

${ }^{80}$ Tamże, IPN Kr 039/27 t. 10, s. 497. Informacja na temat przygotowań do peregrynacji ram obrazu MB Czestochowskiej w Zakopanym (3 XI 1967).
} 
wie, celem uzyskania zezwolenia na przybycie na Podhale obrazu Matki Bożej Częstochowskiej. Miało to miejsce 10 listopada 1967 r. Ponieważ w chwili przybycia delegacji do gmachu WRN nie było w nim przewodniczącego J. Nagórzańskiego, delegację przyjął kierownik Wydziału d/s Wyznań Stefan Pachołek, który w specjalnej notatce opisał jej przebieg. Ton i styl owego dokumentu jest tak charakterystyczny, że należy go przytoczyć tutaj w całości. Świetnie pokazuje on m.in. w jaki sposób urzędnicy władzy ludowej traktowali prośby wierzących:

„Na parę minut przed godzina jedenastą Sekretariat Przewodniczącego Prezydium WRN powiadomił kierownika Wydziału, że zjawiła się w Sekretariacie liczna delegacja górali z Zakopanego, która usiłuje rozmawiać z Przewodniczacym p. Nagórzańskim. Ponieważ Przewodniczący znajdował się w Komitecie Wojewódzkim PZPR, a sprawa dotyczyła naszego resortu wobec czego delegacja ta postanowiła iść do Wydziału ds. Wyznań. Przed przyjęciem tej delegacji kierownik Wydziału usiłował skontaktować się z Wydziałem Administracyjno-Prawnym, jednak ze względu na nieobecność tak kierownika, jak i jego zastępcy, o fakcie delegacji powiadomiono Wydział IV KW MO, a z kolei kierownik nawiazał kontakt telefoniczny $\mathrm{z}$ obecnym w Komitecie tow. Nagórzańskim dla skonsultowania linii rozmowy.

W poczekalni Wydziału stwierdzono, że znajduje się tam 15-osobowa grupa górali w strojach regionalnych i ze chodzi im o Obraz.

Zalecono im wybrać spośród siebie trzechosobową delegację, z którą może rozmawiać kierownik Wydziału. Do biura weszło jednak 4 osoby, dwie kobiety i dwóch mężczyzn i bezpośrednio zapodały, że chodzi im o to, aby Matka Boska Częstochowska mogła ich odwiedzić. Byliśmy już u p. Premiera, tam nam przyobiecano, że Obraz dostaniemy, no ale oni mają tyle pracy teraz, że mogli zapomnieć. W tym miejscu kierownik przerwał ich wywody zwracając się o zapodanie skąd pochodzą, kogo reprezentują itp. Wówczas jedna z kobiet oświadczyła, że stanowią oni delegację dekantu zakopiańskiego i tak: ob. Kaleta Wojciech zam. w Poroninie 75, Maria Trzebunia zam. w Zakopanem ul. Zamoyskiego 5 b, Helena Filipek - Olcza, Droga na Antałówkę 13.

Danych tych udzieli chętnie proponując nawet zapisanie do protokołu pozostałych członków delegacji, a następnie wrócili do meritum sprawy powtarzając już wcześniej wypowiedziane stwierdzenie, że byli w Warszawie u Premiera oświadczając, że im przyobiecał nawet, że Obraz do nich przyjdzie, że wierni dekanatu zakopiańskiego pragnęliby bardzo widzieć u siebie M.B. Częstochowską na to milenium, że w innych już miejscowościach Obraz chodził, to tym bardziej powinien przyjść na Podhale, że ludność góralska jest za rządem oddana Państwu, popiera władzę, ale dzieją się smutne rzeczy, jest dużo chuligaństwa, młodzież krnąbrna i trudna do wychowania. Rozszerza się demoralizacja i gdyby Matka Boska przyszła to mialoby to mieć dobry wpływ szczególnie na młodzież. Dajcie nam tę Matkę Boską, a my wam przyrzekamy, że będzie spokój i porządek, przywieziemy ja pocichutku samochodem zamkniętym do kościoła, wszystko odbędzie się w samym kościele bez pochodów i procesji tak, że 
nawet na ulicach nie będzie ubranych ludzi, a wszyscy ubrani będą tylko w kościele. Strasznie Was o to prosimy, dajcie nam ten Obraz albo dajcie kwitek, to my pojedziemy do Katowic po cichutku i tam Katowice nam wydadzą na Wasz kwitek. My wiemy, że na kwitek nam Katowice wydadzą i gdyby się tutaj Kraków zgodził to wiemy, że Katowice chętnie by nam ten Obraz dały. Tyle by dobrego przyniósł ten Obraz i dzieci by się poprawiły i ludzie stali lepszymi, bo my wierzymy w łaski M.B. Tyleśmy dobrego doświadczyli od niej, od niejednego niebezpieczeństwa nas wybawiła, ratowała nas przed Niemcami w czasie okupacji, ratowała przed Gestapem i tyle by jeszcze dobra mogła zrobić nie tylko dla Podhala, gdyby przyszła do nas, ale i dla calej Polski, gdyby mogła obejść ją cała. Dlaczego mogła być na zachodzie, a nie wolno jej przyjść do nas, pochodów nie będzie, manifestacji też, wszystko odbędzie się w kościele cichutko i spokojnie za to my górale gwarantujemy. Lud będzie trzymał porządek, nawet nie potrzeba będzie milicji.

Po tych wynurzeniach i wypowiedziach z łatwością można było zorientować się, iż ma się do czynienia z osobami stosunkowo ograniczonymi, mocno sfanatyzowanymi w czym celowała obyw. Maria Trzebunia z Zakopanego, kobieta już mocno leciwa licząca chyba ponad 60 lat. Uznano więc za celowe udzielıć wyjaśnień w formie przystępnej, zrozumiałej dla iych prostych ludzi, a w szczególności wyjaśnić to co dla nich jest rzekomo niezrozumiałe dlaczego to Obraz nie może chodzić po całej Polsce skoro władze tolerowały w przeszłości jego wędrówki. W tym miejscu okazało się, że żadna z tych obecnych osób w biurze nie brała udziału w rzekomej delegacji w Premiera, natomiast obyw. Helena Filipek z Olczy brała udział w peregrynacji na ziemiach zachodnich. Ona to wyglądała na osobę inteligentniejszą i stosunkowo młodą, chyba poniżej 40-tu lat, powtarzała jednym tchem - dlaczego robić wyjątki, dlaczego mają być niektóre ziemie uprzywilejowane, a Podhale poszkodowane, przecież ludność góralska znana jest ze swej religijności i polskości.

W spokojny i rzeczowy sposób wyjaśniono obecnym na czym polegała decyzja władz państwowych zakazująca przewożenia Obrazu. Podkreślono, że ten obrządek religijny w roku 1966 przerodził się w manifestację polityczna, która nierzadko była konsekwencją chuligańskich wybryków i antypolskich napisów. Podano też delegacji w tym miejscu, że nie okiełznani młodzieńcy, którzy najpierw skandowali przy Obrazie w drodze powrotnej próbowali demolować sklepy, okna wystawowe, niszczyć majątek społeczny i czy to miało służyć większej chwale M.B.? Naruszono porządek publiczny, zakłócono spokój, rozwydrzone grupy które udawały, że czczą kult obrazu dawały upust swoim niecnym występkom, co dla dobrego katolika powinno oznaczać nie co innego jak profanację tego Obrazu. Organizatorzy uroczystości kościelnych nie napiętnowali takich wybryków, nie potępili chuligańskich wyczynów wobec czego odpowiedzialne za porządek publiczny władze państwowe były zmuszone tak zdecydować. Nie wy układacie porządek uroczystości kościelnych, nie do was należy więc troska o Obraz, sprawa ta jest wyłącznie sprawą władz kościelnych i nawet za to że wy tu przychodzicie władze moga mieć uzasadnione pretensje do waszych duszpa- 
sterzy. Wasze odczucia i doznania o których mówicie z powodu nieobecności Obrazu nie są waszymi odczuciami to mogli wam wmówić tylko duszpasterze.

Po tych wyjaśnieniach, które obecni dwaj mężczyźni przyjmowali raczej spokojnie, obyw. Trzebunia natychmiast zaczęła tak bez związku i treści powtarzać: to góralom się odmawia Obrazu Matki Boskiej, może się zagniewać nie tylko na Podhale, ale i na całą Polskę, a tak gdyby przyszła to by nas pocieszyła, dajcie nam kwitek przywieziemy Ją i odwieziemy cichutko i spokojnie.

Podczas tych wywodów, które okresami przeradzały się w płacz i lamentowanie popadające $w$ jakąś depresję duchową na tle fanatyzmu w mniejszym co prawda już stopniu uzupełniała ja obyw. Helena Filipek, która stwierdziła w pewnym miejscu, ze Ona nie może sobie po prostu tego wyobrazić jakby to jej dzieci nie miały możliwości zobaczyć Obrazu częstochowskiego i że to może zaważyć na ich dalszym życiu.

Obecni dwaj mężczyźni przysłuchiwali się ze względnym spokojem tym lamentom góralek, które ze stanu rozpaczy przechodziły nawet do śmiechu, w końcu Kolata Wojciech z Poronina poprosił o głos, uzupełniały go na zmianę obie kobiety. Ta kopia obrazu panowie dlatego jest taka ważna, że przez samego Piusa XII została poświęcona, a przecież to jest następca samego Chrystusa. My górale przecież samego Jana Kazimierza przed Szwedami obroniliśmy. Jesteśmy za władzami, za naszym Premierem i bardzo bylibyśmy wdzięczni gdyby ta kopia poświęcona przez samego papieźa mogła do nas przyjść, ale jak z tego widać to się chyba nie da, pojedziemy jeszcze chyba do Warszawy, do naszego Premiera, może tam nas wysłuchaja, jak sądzicie panowie - załatwi nam Warszawa? Przyjmujemy wszystkich gości, naszych, zagranicznych, cieszymy się, że możemy gościć u nas i naszego Premiera, no i chcielibyśmy gościć też M.B.

Po tych końcowych wypowiedziach obecnej delegacji pokazana katalog nowych kościołów gdzie już w sposób wizualny obalono ich uwagi o rzekomym ograniczaniu kultu religijnego w Polsce. Jeszcze raz podkreślono przyczyny o zakazie wędrówki Obrazu i odnosiło sie wrażenie, że ich zachowanie zaczęło się stopniowo zmieniać, zaczęli rozumieć bezcelowość ewentualnego wyjazdu do Warszawy, a przy samym rozstaniu zrezygnowali nawet z podtrzymywania jak to mówimy będziemy mieć do Was żal, jak nam nie pozwolicie by Obraz mógł do nas przyjść. Podziękowali nawet za wysłuchanie ich za to że się z nimi tak długo porozmawiało, dodając jednocześnie że smutno jest im tak wracać tak bez niczego i nie zawieźć radosnej nowiny, ale widocznie panowie nie moga tego załatwić no i chyba trzeba was zrozumieć. Najbardziej sfanatyzowana w tej delegacji Trzebunia Maria jak gdyby dawała wyraz swego pojednania głaszcząc rozmówcę po ramieniu i dziękując za posłuchanie i przyjęcie górali z Podhala"81.

${ }^{81}$ Tamże, IPN Kr 039/27 t. 10, k. 480-484. Notatka stużbowa z pobytu delegacji mieszkańców Podhala $w$ Wydziale do Spraw Wyznań Prezydium Wojewódzkiej Rady Narodowej w Krakowie w dniu 10 listopada 1967 roku. 
Protekcjonalny sposób potraktowania delegacji wiernych, odsyłanie ich do innych instancji, stwierdzanie swej niekompetencji - to podstawowe cechy zachowania urzędników Wydziału d/s Wyznań PWRN w Krakowie, które łatwo dostrzec w powyższej relacji. Można też dostrzec próby wbicia klina pomiędzy wiernych i duszpasterzy, kiedy tłumaczy się osobom świeckim, że wydanie zakazu peregrynacji jest skutkiem postępowania księży.

W wielu wypadkach wierni nie udawali się osobiście do urzędów, ale pisali petycje w sprawie uwolnienia obrazu. Trudno ustalić zakres tej akcji, zarówno, co do liczebności takich wystapień, jak też co do liczby urzędów, do których tego typu interwencje kierowano. Z całą pewnością pisma takie kierowano do premiera, Rady Państwa i Urzędu Rady Ministrów. Do tej ostatniej instytucji 28 lutego $1968 \mathrm{r}$. skierował swe pismo Konstanty Czekan z Piotrowic (pow. Oświęcim). Pyta się on urzędników jakim prawem w czasie peregrynacji obraz Matki Bożej Częstochowskiej został zatrzymany na Jasnej Górze. Przecież jeżeli ktoś jest wyznania rzymskokatolickiego, to wolno mu być i ma pełne prawo do wolności sumienia - argumentuje autor pisma i zaraz potem zapytuje: „(...) jakim prawem robi ktoś ze mnie głupiego katolika, co więcej głupiego [nieczytelne - M.T.], któremu wolno jest pokazać puste ramy, bo obraz został uwięziony, a chca go widzieć, to mogą sobie pojechać do Częstochowy". Pismo, które w swoim stylu pokazuje, że napisała je osoba niewykształcona, kończy się znamiennym zdaniem: „Mam prawo żądać sprawiedliwości i nawet starać się ją narzucić". Pismo K. Czekana nie doczekało się odpowiedzi. Urząd Rady Ministrów przekazał je Urzędowi d/s Wyznań w Warszawie $^{82}$.

W marcu do Kancelarii Rady Państwa nadszedł kolejny list z terenu archidiecezji krakowskiej w sprawie peregrynacji. Był to anonim $\mathrm{z}$ terenu Oświęcimia. Jego autorzy, określający się jako chłopi i robotnicy, krytykowali wyznaniową politykę państwa:

„Dziwna druga sprawa to zatrzymanie obrazu Matki Bożej Częstochowskiej z którym wierni obchodzili uroczystości parafialne z okazji rozpoczęcia drugiego Tysiąclecia Państwa Polskiego. Ktoś przematerializowany boi się widoku obrazu. My robotnicy i chłopi $z$ trwogą patrzymy na taka rozbijacką w narodzie robotę, rzucającą cień na wiele dobrych spraw i osiągnięcia Klasy Robotniczej. Władza nasza powinna jednoczyć Obywateli i stwarzać zaufanie wszystkich. niech historia nie wytyka takich błędów, które mogą być usunięte"83.

Również Przewodniczący PWRN w Krakowie otrzymywał pisma, w których mieszkańcy województwa krakowskiego protestowali przeciwko decyzji, którą on firmował swym nazwiskiem. Już na początku listopada 1967 r. na jego ręce wpłynęło anonimowe pismo, którego autorzy określili się mianem „grona studentów

${ }^{82}$ AAN, Ud/sW, syg. 82/38, k. 5. Pismo K.Czekana do Urzędu rady Ministrów (28 II 1968); Tamże, k. 4. Pismo Urzédu rady Ministrów do Urzędu d/s Wyznań (luty 1968).

${ }^{83}$ Tamże, syg. 82/38, k. 27. Pismo anonimowe do Kancelarii Rady Państwa z marca $1968 \mathrm{r}$. 
i absolwentów UJ". Podpisy pod owym dokumentem były specjalnie skrócone i ograniczały się do podania imienia $\mathrm{z}$ inicjałem nazwiska osób piszących. Przewodniczący przekazał sprawę anonimu $\mathrm{SB}^{84}$.

Autorzy powyższego pisma zwrócili się do Przewodniczącego PWRN w Krakowie w imieniu młodzieży województwa krakowskiego. W ich opinii uwięzienie obrazu Matki Bożej Częstochowskiej budzi tylko niepotrzebną sensację, a „mieszkańcom województwa nie wystarcza w dziedzinie kultu religijnego sensacja". Cała akcję z niedopuszczeniem obrazu do peregrynacji w archidiecezji uznano za naruszenie wolności wyznania i sumienia oraz za wandalizm. Pismo kończy się następującym stwierdzeniem: „Jeśli przedstawiciele naszych władz miejskich i wojewódzkich uważają oglądanie pustych ram za wystarczające «przeżycie religijne» dla wierzących, zaś dla niewierzących za artystyczne - to sąd o przedstawicielach władzy nie może być korzystny. Nie zamierzamy «obrażać» przedstawicieli władz, nie "wypada także" radnym lekceważyć naszych próśb. Prosimy o przekazanie na ręce krakowskich biskupów zezwolenia na przywiezienie do Nowego Targu obrazu Matki Bożej z Jasnej Góry" ${ }^{25}$.

\section{ZAKOŃCZENIE}

Władze państwowe i partyjne $z$ wielką podejrzliwością patrzyły na zapoczątkowaną przez prymasa S. Wyszyńskiego w 1957 r. w Polsce peregrynację kopi obraz Matki Bożej Częstochowskiej. Początkowo zdecydowanie nie ingerowały jednak w jej przebieg. Kiedy jednak lata sześćdziesiąte przyniosły zaostrzenie relacji między Kościołem a państwem, związane w sposób szczególny z obchodami uroczystości milenijnych, peregrynacja stała się tą płaszczyzną działalności Kościoła, którą należało ograniczyć, a nawet jak planowano, całkowicie jej zakazać.

W 1966 r. władze zdecydowały się po raz pierwszy użyć siły wobec samego obraz w czasie jego wędrówki po stolicach biskupich Polski z racji uroczystości milenijnych, jak i wobec osób, które mu towarzyszyły. W czasie przewożenia obraz był kilkakrotnie zatrzymywany, zmieniano trasę jego przejazdu, okrywano go dla niepoznaki plandeka. Zwieńczeniem tego typu działań było zatrzymanie samochodu i obrazu, który przewożono w dniu 2 września z Warszawy do Katowic, gdzie to miała rozpocząć się właśnie jego peregrynacji po parafiach diecezji katowickiej. Obraz w otoczeniu sił milicyjnych został odtransportowany na Jasną Górę i tam pozostawiony pod kontrolą sił bezpieczeństwa. Przed klasztorem stały posterunki milicyjne i rewidowały samochody opuszczające budynku klasztorne, szukając, czy nie wywozi się obraz Nawiedzenia.

\footnotetext{
${ }^{84}$ IPN Kr, syg. IPN Kr 039/27 t. 13, k. 587. Telefonogram do Wicedyrektora Gabinetu Ministra Spraw Wewnętrznych (Kraków, 8 XI 1967).

${ }^{85}$ Tamże, syg. IPN Kr 039/27 t. 13, k. 580. Meldunek do Naczelnika Wydzialu IV Departamentu IV MSW (Kraków, 11 XI 1967).
} 
Zatrzymanie kopii ikony jasnogórskiej stanowiło na początku pewien problem, albowiem stawiało pod znakiem zapytania sens peregrynacji, czyli wędrówki obrazu. W diecezji śląskiej zaczęto w owej sytuacji w miejsce obrazu eksponować inne symbole maryjne, np. świecę, bądź ewangeliarz. Najczęściej jednak w miejsce nieobecnego obrazu Nawiedzenia pojawiła się pusta rama. Także w czasie Nawiedzenia w diecezji katowickiej zaczęto pogłębiać duchowy sens peregrynacji. Nie miała to już być wędrówka obrazu, ale Nawiedzenie parafii przez Matkę Bożą.

Archidiecezja krakowska była z kolej druga polską diecezją, w której peregrynacja odbywała się bez udziału kopii obrazu jasnogórskiego. W 1967 r. kard. $\mathrm{K}$. Wojtyła podjął pertraktację $\mathrm{z}$ władzami wojewódzkimi oraz państwowymi w celu zwolnienia obrazu z Jasnej Góry i zapewnienia jego udziału w Nawiedzeniu. Wszystkie owe starania rozbijały się jednak o twarde stanowisko władz, które wykorzystując swą wypróbowana praktykę próbowały nawet wydać całkowity zakaz odbywania peregrynacji w archidiecezji. Zakazowi temu Kościół krakowski się nie podporządkowal, albowiem obchody Nawiedzenia prowadzone były w budynkach kościelnych i miały ściśle religijny charakter, a więc w tym wypadku nie była konieczna zgoda na ich odbycie ze strony urzędów wojewódzkich bądź państwowych.

Jesienią 1967 r. wśród duchowieństwa i wiernych archidiecezji panowały dość optymistyczne nastroje, co do obecności kopii obrazu Matki Bożej Częstochowskiej w czasie Nawiedzenia. Sądzono, że skoro metropolita zwrócił się z prośbą w tej kwestii do samego premiera, władze nie będą chciały zaostrzać konfliktu z wierzącymi i uczynią ów gest w stosunku do kardynała, któremu bardzo zależało na obecności obrazu. Nawet wówczas, kjedy ze strony przewodniczących PWRN i PRN m. Krakowa w imieniu premiera J.Cyrankiewicza nadeszła odmowna odpowiedź na prośbę kard. K. Wojtyły i choć prowadzono peregrynacje bez obrazu przy pustych ramach, dalej wierzono, że w pewnym momencie władze zmienią swoją decyzję.

W końcu marca 1968 r. kard. K. Wojtyła ponownie zwrócił się do władz o zwolnienie obrazu z Jasnej Góry i zezwolenie na jego udział w peregrynacji. Termin owej interwencji i prośby jest nieprzypadkowy. Kościół i Episkopat polski $\mathrm{z}$ rezerwą traktował wydarzenia marca ' 68 , widząc w nich wewnętrzne rozgrywki w obozie partyjnym. Protesty biskupów polskich budziła brutalizacja życia politycznego i społecznego, prześladowanie opozycji oraz dopominającej się sprawiedliwości młodzieży. I w tych kwestiach zabierali oni głos. Jednakże władza z życzliwością obserwowała, że Kościół nie angażuje się bezpośrednio w rozgrywki marcowe. Był to zapewne dogodna chwila, aby kiedy to w czasie odprezżenia po kryzysie społecznym, upominać się o zwolnienie obrazu. Gdyby do tego doszło byłby to zapewne sygnał demokratyzacji życia i fakt ów przyczyniłby się w znacznym stopniu do uspokojenia nastrojów społecznych. Władza jednak i tym razem zlekceważyła prośby krakowskiego kardynała. Do grudnia 1968 r., kiedy to zakoń- 
czono Nawiedzenie archidiecezji krakowskiej, nie udało się sprowadzić obraz na trasę peregrynacji.

Bardzo trudno ustalić jaki był zakres starań osób świeckich oraz duchowieństwa archidiecezji o zwolnienie obrazu Matki Bożej z Jasnej Góry w 1967 i 1968 r. Z cała pewnością takie starania były. Na początku listopada 1967 r. delegacja mieszkańców Podhala udała się do Prezydium WRN w Krakowie. Co jakiś czas duchowni i osoby świeckiej kierowały pisma protestacyjnej i petycje o dopuszczenie obrazu Nawiedzania do peregrynacji do premiera J. Cyrankiewicza, Urzędu Rady Ministrów oraz Rady Państwa. W większości były to pisma anonimowe, albowiem ich autorzy obawiali się represji ze strony władz.

Nawiedzenie $w$ archidiecezji krakowskiej udowodniło, że nawet pomimo nieobecności obrazu Matki Bożej Częstochowskiej, może ono być kontynuowane i może przynosić owoce duchowe. Głębiej zrozumiano w owym czasie, że peregrynacja nie polega jedynie na fizycznej obecności cudownego obrazu, lecz jest rzeczywistością duchowej obecności Matki Bożej w konkretnej wspólnocie parafialnej. Pomimo, iż w większości parafii archidiecezji musiano wystawić puste ramy w miejscu, gdzie miał być wiernym ukazany obraz Królowej Polski, to Nawiedzenie spełniło swe cele - wierni przystępowali do spowiedzi i Komunii św., zawierali sakrament małżeństwa, często po długim okresie życia jedynie w związku cywilnym, jednali się z sąsiadami i przede wszystkim odczuwali, że Matka Boża rzeczywiście jest przy nich. 